\title{
Guinea Factors, Slave Sales and the Profits of the trans-Atlantic Slave Trade in Late Eighteenth-Century Jamaica: The Case of John Tailyour ${ }^{1}$
}

Slave trading merchants played a crucial role in the creation of the Atlantic World. Their ships carried off almost thirteen million captive Africans, doing much to shape the histories of Europe, Africa and the Americas. Historians have, as a result, been drawn to the study of slave trading merchants, and have explained how they organized their businesses and profited by the trade Although profits from the slave trade were not, as Eric Williams postulated, sufficient to drive British industrial development, more recent scholarship has shown that slaving merchants still played an important role in the creation of Britain's commercial empire. As David Hancock demonstrated in his seminal Citizens of the World, slave traders "integrated the empire as they integrated their businesses," by linking plantations in the Americas with African slaving depots via British capital and ships. Other historians have turned their attention to African slave traders, and explored how they created complicated cross-cultural credit mechanisms to facilitate the slave trade that relied, in particular, on personal family and trust networks. We thus possess a thorough understanding of how slave traders operated their businesses in Europe and, to a lesser extent, Africa, and their role in forcibly shipping millions of enslaved Africans across the Atlantic. ${ }^{2}$

\footnotetext{
${ }^{1}$ Nicholas Radburn is a PhD candidate at the Johns Hopkins University. He would like to thank the participants in the Johns Hopkins Early American Seminar for their insightful comments on an early draft of this article. He would also like to thank Philip D. Morgan, Stephen D. Behrendt, Sheryllynne Haggerty, Daniel Livesay, and Katherine Smoak for reading later versions of this article, and the anonymous reviewers for the William and Mary Quarterly for their constructive criticism. He is especially grateful to the staff at the William L. Clements library, for facilitating his research on the Tailyour Family papers.

${ }^{2}$ Statistics for the slave trade are taken from Voyages: the trans-Atlantic slave trade database, available from www.slavevoyages.org (hereafter Voyages). For the slave trade's profitability, see James Wallace, A General and Descriptive History of the Ancient and Present State, of the Town of Liverpool, (Liverpool, 1795), pp.193-255; Gomer Williams, History of the Liverpool Privateers and Letters of Marque..., (Liverpool, 1897), pp.594-608. Eric Williams, Capitalism and Slavery, (London, 1944), p.36. Stanley Dumbell, "The Profits of the Guinea Trade," Economic History Supplement to Economic Journal, 2, (1931), pp.254-257; Roger Anstey, The Atlantic Slave Trade and British Abolition 1760-1810 (London, 1975), p.46; David Richardson, "Profits in the Liverpool Slave Trade: The Accounts of William Davenport," in Roger Anstey and Paul Hair eds., Liverpool, the African Slave Trade, and Abolition (Liverpool, 1979), pp.60-90; Joseph E. Inikori, "Market Structure and the Profits of the British African Trade in the Late Eighteenth Century," The Journal of Economic History, 41 (Dec. 1981), pp.745-776. David Hancock, Citizens of the World: London Merchants and the Integration of the British Atlantic Community, 1735-1785 (Cambridge,
} 
Absent from this otherwise excellent literature is research on American slave traders, or "Guinea Factors" as they were known to contemporaries. Established in American port towns, Guinea factors conveyed almost two million African captives from ship to shore in the British Americas in the second half of the eighteenth century, extended credit to planter purchasers, and brokered return shipments of slave-grown produce to Britain. Guinea factors were thus the crucial nexus between the trans-Atlantic slave trade and the plantation complex. Despite their importance, we lack the names and backgrounds of American slave traders, knowledge of the process by which they sold slaves, managed their businesses, and profited from the slave trade, a result, in part, of a divide between the historiographies of the trans-Atlantic slave trade and American slavery. Historians of the slave trade have quantified and described the transportation of captives on the notorious Middle Passage, a voyage that concluded for the slaves when the ship arrived in the Americas. Historians of colonial slavery, by contrast, have studied slaves after they arrived at the plantation, and have paid little attention to how they were purchased and seasoned. Guinea factors and the slave sales they arranged fall between these two areas of studies, and have, therefore, been overlooked. $^{3}$

1995), p.3 (quote). For recent scholarship on slave trading merchants in Britain, see, for example, Jane Longmore, "Cemented by the Blood of a Negro?' the Impact of the Slave Trade on Eighteenth Century Liverpool," in Liverpool and Transatlantic Slavery, ed. David Richardson, Suzanne Schwarz, and Anthony Tibbles, (Liverpool: 2007), pp.227251; David Pope, "The Wealth and Social Aspirations of Liverpool's Slave Merchants of the Second Half of the Eighteenth Century," in Ibid., pp.164-226; Stephen D. Behrendt, "Human Capital in the British Slave Trade," in Ibid., pp.66-97; Kenneth Morgan, "James Rogers and the Bristol Slave Trade," Institute of Historical Research, 76, 192 (May 2003), pp. 189-216; Stephen D. Behrendt, "Markets, Transactions and Cycles," WMQ, 3rd Ser., 58 (Jan. 2001), pp.171-204. For recent work on African slave traders, see, for example, Randy J. Sparks, Where the Negroes Are Masters: An African Port in the Era of the Slave Trade (Cambridge, MA: 2013); Stephen D. Behrendt, A. J. H. Latham and David Northrup eds., The Diary of Antera Duke, an Eighteenth-Century African Slave Trader (Oxford: 2010); Paul E. Lovejoy and David Richardson, "'This Horrid Hole': Royal Authority Commerce and Credit at Bonny, 16901840", Journal of African History, 45 (2004), pp.363-392; Paul E. Lovejoy and David Richardson, "Trust, Pawnship, and Atlantic History: the Institutional Foundations of the Old Calabar Slave Trade," American Historical Review, 104 (1999), pp.333-355.

${ }^{3}$ For Jamaican slave sales and factors, see Sheryllynne Haggerty “"Merely for Money'? Business Culture in the British Atlantic, 1750-1815 (Liverpool, 2012), pp.179-188; Kenneth Morgan ed., The Bright-Meyler papers: a Bristol-West India connection, 1732-1837 (Oxford, 2007); Trevor Burnard and Kenneth Morgan, "The Dynamics of the Slave Market and Slave Purchasing Patterns in Jamaica, 1655-1788," WMQ, 3rd Ser., 58 (Jan. 2001), pp.205-228; Jackie 


\section{Guinea Factors in Jamaica}

The case of John Tailyour does much to fill this lacuna. Tailyour was born into an affluent family in Marykirk, Scotland, on 29 February 1755 and apprenticed as a tobacco factor in Virginia until 1775, when the economic calamities of the American Revolutionary War forced him to leave the colony. After fruitlessly traversing the Atlantic during the war, Tailyour turned to his Jamaican cousin Simon Taylor - one of the richest sugar planters in the British Atlantic — to establish him as a Kingston "town" factor, an eighteenth-century term used to describe port-based importers of plantation goods. In 1785, two years after his arrival in Kingston, Tailyour began importing and selling captive Africans as a Guinea factor, a business he pursued until July 1792, when he departed Jamaica for England, and acted as an agent for his company. In 1796, he retired from slave trading and returned to his native Scotland, aged just forty-one, where he died nineteen years later as a rich man. Over the course of a lucrative twelve-year career as a Guinea factor, Tailyour and his partners sold 17,374 enslaved Africans from fifty-five vessels, without ever directly investing in slave ships, making him Jamaica's second largest slave trader (Table 1).

John Tailyour's time as one of the leading Guinea factors in the Atlantic World is recorded in his personal papers, perhaps the most extensive of any British American slave merchant, which have not yet been utilized by historians of the trans-Atlantic slave trade, having only been unearthed in 2002. Tailyour's voluminous records thus provide an ideal source base from which

\footnotetext{
Ranston, The Lindo Legacy (London, 2000), pp.29-66; Eli Faber, Jews, Slaves, and the Slave Trade: Setting the Record Straight (New York, 1998), pp.57-90; Trevor Burnard, "Who bought Slaves in Early America? Purchasers of Slaves from the Royal African Company in Jamaica, 1674-1708," Slavery \& Abolition, 17 (1996), pp.68-92. For other colonies, see Sean Kelley, "Scrambling for Slaves: Captive Sales in Colonial South Carolina," Slavery \& Abolition, 34 (2013), pp.1-21; Stephanie E. Smallwood, Saltwater Slavery: A Middle Passage from Africa to American Diaspora (Cambridge, 2006), pp.153-181; Douglas J. Hamilton, Scotland, the Caribbean and the Atlantic world (Manchester, 2005), pp.84-111; David Hancock, “'A World of Business to Do’: William Freeman and the Foundations of England's Commercial Empire, 1645-1707," WMQ, $3^{\text {rd }}$ ser., 57 (Jan. 2000), pp.3-34. Kenneth Morgan, "Slave Sales in Colonial Charleston," English Historical Review, 113 (Sept. 1998), pp.905-927; David Galenson, Traders, Planters, and Slaves: Market Behavior in Early English America (Cambridge, 1986), pp.71-85; Darold D. Wax, "New Negroes Are Always in Demand": The Slave Trade in Eighteenth-Century Georgia, The Georgia Historical Quarterly, 68, No. 2 (Summer, 1984), pp. 193-220. W. Robert Higgins, "Charles Town Merchants and Factors Dealing in the External Negro Trade 1735-1775,” The South Carolina Historical Magazine, 65 (Oct. 1964), pp.205-217.
} 
to analyze the business history of an American slave trader, and allow us to see how and why young men like Tailyour entered the Guinea factoring business, how they managed their businesses, and how they profited from the slave trade. Tailyour's papers, when combined with the records of planters and British slave traders, also cast light on American slave sales, allowing us to see how factors divided and then channeled enslaved Africans to plantations and foreign colonies in the second half of the eighteenth century, sometimes via the notorious "scramble sale." Through the case of John Tailyour, we will see, then, how Guinea factors played an important role in the economic history of the trans-Atlantic slave trade, and the forced migration of captives within the Americas. ${ }^{4}$

Insert Table 1 Here

John Tailyour first entered business in 1770, when his father Robert, an influential overseas merchant in Montrose, a small port town in the Lowland region of Eastern Scotland, secured him an apprenticeship to Henry Mitchell and George McCall, Glasgow tobacco traders. Tailyour began his apprenticeship in Glasgow, where he was presumably taught the rudiments of accounts and

\footnotetext{
${ }^{4}$ Tailyour was baptized in Montrose on 18 June 1755 (General Registry Office for Scotland, 312/00). The Tailyour Family Papers (hereafter TFP) are held at the William L. Clements Library, The University of Michigan (hereafter WCL). Simon Taylor's correspondence with his cousin are lodged at the Commonwealth Institute, London, and are available on microfilm (The Taylor and Vanneck-Arcedekne Papers, Plantation Life in the Caribbean (hereafter PLC), (Marlborough, 2005), XIV). Daniel Livesay, who studied John Tailyour's mixed race family, is the only scholar to have used the papers to date ("Children of Uncertain Fortune: Mixed-Race Migration from the West Indies to Britain, 1750-1820," (PhD thesis, University of Michigan, 2010)). There are only two other sets of papers relating to British American slave traders of a similar size to Tailyour's: those of Henry Laurens, a Charleston slave trader during the 1750s and 1760s who went on to be an American Revolutionary leader (David R. Chesnutt and C. James Taylor eds., The papers of Henry Laurens (Columbia, S.C., 1968-2003); Austin \& Laurens Account Book April 1750- December 1758, Beinecke Rare Book and Manuscript Library (hereafter BRBML), Yale University, GEN MSS VOL 184); and those of the Bright-Meyler family, who operated as Jamaica Guinea factors from the 1740s until 1775 (Morgan ed., Bright-Meyler). There are papers for the Liverpool firms Case \& Southworth and Rainford, Blundell \& Blundell and, at an earlier date, Buchanan \& Simpson but these are dwarfed by the Tailyour papers (Liverpool Record Office (hereafter LRO), MD33-36; Rainford Family Papers, LRO, 920 CHA/1; National Archives of Scotland (hereafter NAS), CS96/502-9).
} 


\section{Guinea Factors in Jamaica}

finances, before departing for Fredericksburg, Virginia, where his company operated a store managed by Mitchell. Arriving in late 1774, Tailyour was advised by his father, who had himself lived abroad as a factor, to develop his rudimentary French skills, cultivate the "principle of attention" to business, avoid idleness, and "perfect a knowledge of the country of Virginia," particularly the "method of cultivating the Tobacco." Tailyour was also to inform himself of the names of the "Indian nations," and the "number of Negro slaves" in the colony. When not busy acquainting himself with the colony, Tailyour was expected to assist Mitchell by selling imported goods to the planters, and remitting tobacco back to Britain. Through the business, Tailyour gained a thorough understanding of the functioning of a slave colony, the tobacco trade, the creditworthiness of the planters, and financial accounts, all skills that would prove useful in Jamaica. He must have excelled, because he was "admitted to be a partner" upon completion of his apprenticeship and hoped to remain in Virginia as a tobacco factor. Like many Glasgow tobacco firms, Mitchell \& McCall began to call in their Virginian debts at the onset of the American Revolution, forcing Tailyour to return to Scotland in August 1775. Although the war had "put an end" to his firm's Virginia tobacco business, he remained a partner in Mitchell \& McCall, which in 1777 sent him to New York to supply goods to the British army. The venture must have been a failure because Tailyour set sail for Glasgow sometime in 1778 "with no intention of ever going out [to America] again," at which point he terminated his connection to Mitchell \& McCall, who had "resolved not to carry on any more Trade." On his return home, Tailyour discovered that his father had died, obliging his family to put their Kirktonhill and Balmanno country estates up for sale. $^{5}$

\footnotetext{
${ }^{5}$ Robert Tailyour had worked as a merchant in Lisbon during the 1740s for which, see Partnership Agreement of Robert Tailyour and John Bannister, Lisbon, 16 Feb. 1743, TFP, WCL, Box 6. Robert Tailyour to John Tailyour, Kirktonhill, 15 Apr. 1775, Commonplace Book of Robert Taylor, TFP, WCL, Box 12 ("principle" quote). For the Tailyour family history see the genealogical records in TFP, WCL, Box 11. For Tailyour's early career, see John
} 
Unemployed, Tailyour moved to London where, tired of waiting for peace, he decided to return once more to North America and not come back to Britain until he was "either possessed of a fortune or in the way of mak[in]g one." Tailyour pooled his capital with his younger brother Hercules, who had also apprenticed with Mitchell \& McCall, purchased an assortment of goods, and, in June 1781, sailed for New York. Upon his arrival there he found to his horror that the British Army had surrendered at Yorktown a few weeks earlier. He nevertheless tried to establish himself as a merchant, aided by letters of introduction to Scottish army officers, but with markets low from an influx of prize goods, he could make little from his cargo. A scheme to sell guns to the army in partnership with a Glasgow merchant house likewise turned out badly. Looking beyond New York, Tailyour used his army contacts to secure a potentially lucrative position as a deputy quarter master to the British prisoners held in Lancaster, Pennsylvania for which he received a substantial salary, and permission to sell his own goods to the imprisoned army officers. The scheme failed, though, when the local committee of safety confiscated his stock of goods, accusing him of having traded illegally. ${ }^{6}$

Tailyour to Simon Taylor, London, 6 June 1781, PLC, XIV/1 (“admitted" quote). For the Glasgow tobacco trade, see Alan L. Karras, Sojourners in the Sun: Scottish Migrants in Jamaica and the Chesapeake, 1740-1800 (Ithaca, 1992); Jacob M. Price, Capital and Credit in British Overseas Trade: The View from the Chesapeake (Cambridge, MA., 1980); T.M. Devine, The Tobacco Lords: A Study of the Tobacco Merchants of Glasgow and their Trading Activities, c.1740-90 (Edinburgh, 1975); J.H. Soltow, "Scottish Traders in Virginia," Economic History Review, 12 (1959), pp.83-98; Jacob M. Price, "The Rise of Glasgow in the Chesapeake Tobacco Trade, 1707-1775," WMQ 3rd Ser., 11, 2 (Apr., 1954), pp. 179-199. For the closure of Mitchell \& McCall's Virginia business, see The Virginia Gazette, Williamsburg, 11 August 1775, 23 August 1776, 28 February 1777; Devine, Tobacco Lords, pp.103-152, 118. For the difficulties faced by Glasgow tobacco firms during the American Revolution, see T.M. Devine, "Glasgow Merchants and the Collapse of the Tobacco Trade 1775-1783," The Scottish Historical Review, 52, (Apr., 1973), pp.50-74; Karras, Sojourners, pp.188-210; M.L. Robertson, "Scottish Commerce and the American War of Independence," The Economic History Review, New Ser., 9, (1956), pp. 123-131. John Tailyour to Simon Taylor, London, 6 June 1781, $P L C, \mathrm{XIV} / 1$ ("put," "intention" and "resolved" quotes). For the sale of the Tailyour family estates, which left John Tailyour an inheritance of just $£ 400$, see Andrew Jervise, Epitaphs and Inscriptions from Burial Grounds and Old Buildings in the North East of Scotland..., 1, (Edinburgh, 1879), p.134. For Tailyour's time in New York, see The New York Gazette, New York, 9 February 1778, 23 November 1778.

${ }^{6}$ Tailyour's time in New York, Pennsylvania and first two years in Jamaica, are detailed in his letterbook, which covers the period 1781-1785. For Tailyour's joint cargo with his brother and his Pennsylvania venture, see John Tailyour to Hercules Tailyour, Kingston, 7 December 1781, 17 January 1782 ("either" quote), 3 March 1782, 31 March 1782, 13 September 1782, 31 October 1782 TFP, 19 November 1782, 20 December 1782, WCL, TFP, Letterbook 1781-5. For Tailyour's Pennsylvania venture, see also Report on American Manuscripts in the Royal 


\section{Guinea Factors in Jamaica}

Tailyour returned to New York from Pennsylvania and resolved to join his second cousin Simon Taylor in Jamaica. Although Tailyour had never met his cousin, he knew him by reputation, and had written to him prior to leaving London for New York, requesting consignments of sugar and rum from Jamaica. Simon Taylor's father Patrick Tailzour, like John Tailyour's father Robert, hailed from Borrowfield, a small village thirty miles north of Montrose, but had left at a young age for Kingston, Jamaica, where he established himself as a merchant. His son Simon had been born in Jamaica in 1740, attended school at Eton, and trained as a merchant in Holland but, unlike many of his absentee contemporaries, returned to Jamaica in 1760 upon the death of his father and resided there permanently. Trading as a Guinea and town factor through his firm Taylor \& Graham, while also acting as an attorney for Chaloner Arcedeckne, the absentee scion of an Irish family with large land holdings in Jamaica, Taylor built a substantial fortune which he re-invested in a number of sugar plantations and livestock pens. When his cousin contacted him, Taylor owned and managed at several thousand slaves spread across several parishes, making him one of largest planters in the British Atlantic world. As a magistrate, militia colonel and planter in Saint-Thomasin-the-East - which contained, Edward Long writes, some of the "finest sugar-plantations in the island"-Taylor was also well acquainted with Jamaica's elite planters. "In short," John Tailyour wrote, "he is a man of fortune equal to any person residing in Jama[ica] \& I think he is of greater influence than any man in it." Although Simon Taylor could do little for Tailyour in New York, he did want a relative present to help manage his affairs, and told him in September 1781 that he should come to Jamaica. Having repeatedly failed in North America, Tailyour decided to take up his cousin's offer, and wrote to him in September 1782 that he would leave as soon as possible. ${ }^{7}$

\footnotetext{
Institution of Great Britain,3, (Hereford, 1907), pp.12-3, 94, 127, 145, 230, 243-4. For the gun scheme, see John Tailyour to Robert Dunmore, New York, 16 January 1782 and 27 March 1782, WCL, TFP, Letterbook 1781-5.

${ }^{7}$ For Simon Taylor and Chaloner Arcedeckne, see R.B. Sheridan, "Simon Taylor, Sugar Tycoon of Jamaica, 17401813," Agricultural History, 45, 4 (Oct. 1971), pp.285-96; B.W. Higman, Plantation Jamaica, 1750-1807, Capital
} 
Tailyour set sail for the West Indies on 13 January 1783, leaving behind a number of outstanding debts owed to him from his numerous unsuccessful speculations. He was owed £6700 from the Lancaster adventure, an assortment of unsaleable and rusty guns remained in New York, and his $£ 350$ share in Mitchell \& McCall was locked up in bad Virginia debts. His initial venture with his brother also "turned out very ill," and yielded a $£ 30$ loss on his initial $£ 1,000$ investment, the proceeds of which he invested along with his remaining capital of approximately $£ 500$ in a brig, which he hoped to sell in the West Indies at a profit. Arriving at Tortola in March 1783, Tailyour's sanguine hopes for his voyage were dashed when rumors of peace drove down the price of his vessel, which he had to sell at a loss and for a bill of exchange that was subsequently protested. Tailyour persevered, however, and re-invested his remaining capital of $£ 1,500$ in a prize ship laden with lumber which, he believed, would fetch a high price in Jamaica. Tailyour's run of bad luck continued when, on 19 March 1783, he arrived in Kingston at precisely the same moment as newspapers carrying news of peace, instantly reducing the price of lumber, and leaving him a loss of $£ 500$ on the venture, leaving him approximately $£ 1,000$ sterling as capital to invest in Jamaica. $^{8}$

and Control in a Colonial Economy (Mona, 2005), pp.137-146; Betty Wood ed., "The Letters of Simon Taylor to Chaloner Arcedeckne," in Travel, trade and power in the Atlantic, 1765-1884, Camden miscellany, 5th Ser., 35 (Cambridge, 2002), n.5. Simon Taylor traded in partnership with his brother-in-law Robert Graham from June 1764 until Graham's departure from Jamaica in 1771 for which, see the Graham of Gartmore papers (hereafter GGP), National Library of Scotland (hereafter NLS), Acc.11335. Edward Long, The History of Jamaica, 2 (London, 1774), pp.167-8 ("finest" quote). John Tailyour to Hercules Tailyour, Kingston, 7 June 1783, Ibid. ("man of fortune" quote). For Tailyour's decision to leave New York, see John Tailyour to Hercules Tailyour, Kingston, 17 January 1782, TFP, WCL, Letterbook 1781-5; John Tailyour to Simon Taylor, New York, 9 September 1782, TFP, WCL, Letterbook 1781-5.

${ }^{8}$ For Tailyour's share in Mitchell \& McCall, see John Tailyour to A. Thomson, New York, 30 October 1782, TFP, WCL, Letterbook 1781-5. John Tailyour to Hercules Tailyour, Kingston, 13 January 1783, Ibid. ("turned" quote). For the ship schemes, see John Tailyour to John \& Alexander Anderson, New York, 13 January 1783, Ibid.; John Tailyour to John \& Alexander Anderson, Tortola, 7 March 1783, Ibid.; John Tailyour to Campbell \& Hagart, Kingston, 25 March 1783, Ibid. After his departure from New York, Tailyour employed an attorney who forwarded monies recovered from Lancaster for which, see John Tailyour to John McKenzie, Kingston, 13 January 1783, 1 April 1783, 13 July 1783, 5 August 1783, 29 October 1783, Ibid.. Tailyour summarized his parlous finances to his uncle in March 1784: he had $£ 4-500$ sterling owing from the army for the Lancaster scheme, $£ 650$ locked up in the protested bill for the sale of his vessel in Saint Thomas, so that his "ready cash is small" (John Tailyour to George Carnegie, Kingston, 


\section{Guinea Factors in Jamaica}

Despite his failures, Tailyour had great hopes for success in Kingston, one of the most prosperous ports in the British Atlantic. Kingston was the locus of white society in Jamaica, a bustling city of 20,000 people, larger than Charleston and Boston, and almost the size of New York. Hundreds of ships sailed into Kingston's busy harbor every year, bringing in British manufactures and American plantation stores, and exporting the island's crop of sugar and coffee. Kingston also acted as the hub of Jamaica's slave trade. In 1784, 250,000 African slaves toiled in Jamaica, a population that needed to be constantly replenished by an annual importation of several thousand "new negroes," almost all of whom passed through a complex of wharves and stores on Kingston's waterfront. Jamaica's small population of whites grew incredibly rich from these Africans' labor, giving each a per capita wealth that far exceeded their British and North American counterparts. In relocating from New York to Kingston, Tailyour moved from British America's rapidly collapsing periphery to its most prosperous core. ${ }^{9}$

Shortly after Tailyour's arrival, his cousin proposed to put him into business as a "Town Factor." As Tailyour described, "factorage" involved "selling rum \& sugar \& ca," and "supplying

20 March 1784, Ibid.). Tailyour does not seem to have received compensation for the goods confiscated at Lancaster, and was also unoptimistic about recovering the debts from the gun business or his Mitchell \& McCall debts. In August 1788, Tailyour he had a sum of money owed him from the gun scheme and, in the next year, he complained to a Virginia correspondent that he had "long looked on what property I had in Virginia as lost" (John Tailyour to Robert Dunmore, Kingston, 1 August 1788, TFP, WCL, Letterbook 1788-9; John Tailyour to William Gillies, Kingston, 10 January 1789, TFP, WCL, Letterbook 1788-9).

${ }^{9}$ For Jamaica's economic prosperity, see Trevor Burnard, “Prodigious Riches:” The Wealth of Jamaica before the American Revolution," The Economic History Review, New Ser., 54 (Aug. 2001), pp.506-524; Trevor Burnard, "European migration to Jamaica," WMQ, 3rd. ser., 23 (1996), pp.769-796; Peter A. Coclanis, "The Wealth of British America on the Eve of the Revolution," The Journal of Interdisciplinary History , 21 (Autumn, 1990), pp. 245-260; R.B. Sheridan, "The wealth of Jamaica in the eighteenth century," The Economic History Review, 2nd ser., 18 (1965), pp.292-311. For Kingston, see Trevor Burnard, "The Grand Mart of the Island”: The Economic Function of Kingston, Jamaica in the Mid-Eighteenth Century," in K. Monteith and G. Richards eds., Jamaica in Slavery and Freedom (Mona, 2002), pp.225-241; Colin G. Clark, Kingston, Jamaica: Urban Development and Social Change, 1692-1962 (Berkeley, 1975), pp.5-28; B.W. Higman, "Jamaican Port Towns in the Early Nineteenth Century," in Franklin Knight and Peggy K. Liss eds., Atlantic Port Cities: Economy, Culture and Society in the Atlantic World, 1650-1850 (Knoxville, 1991), pp.117-148. For the slave trade to Jamaica, see Burnard and Morgan, "Dynamics"; R.B. Sheridan, "The Slave Trade to Jamaica, 1702-1808," in B.W. Higman ed., Trade, Government and Society in Caribbean History, 1700-1920: Essays Presented to Douglas Hall (Kingston, 1983), pp.1-16. 


\section{Guinea Factors in Jamaica}

the [plantations] with diff[eren]t articles they want, such as lumber, flour \& ca," all for a commission, a similar business to the Virginia tobacco trade. Tailyour also helped to ship his cousin's sugar back to Britain, and was scheduled to act as his attorney during an anticipated absence from Jamaica, a trip that was ultimately cancelled in March 1784 when a fire gutted Taylor's Lyssons sugar estate. The newcomer believed that his cousin could "throw a great deal of commission business into my hands" by persuading his planter friends to make their own purchases of plantations stores from him. This business was, Tailyour opined three months after his arrival, "the most desirable in the Island, its [sic] both the most considerable \& most profitable," offering returns of, according to Tailyour, “£700-1,000 sterling per ann[um] \& every year must increase it." Being a commission business, these profits also promised to be much less risky than speculative ventures, something that Tailyour now had a strong aversion to; as he advised his brother Hercules, the key to success in trade was to "get into a steady line," rather than "adventuring" ones capital. ${ }^{10}$

On 1 January 1784, Tailyour began his town factoring business with Angus McBean and Thomas Bagnold, two Scots who had worked as clerks for Taylor \& Graham in the 1760s and 1770s. Upon the departure of Robert Graham from Jamaica in 1771, Taylor had put his employees into business on their own account. As Tailyour described, their house "have had all" of Simon Taylor's business since their establishment "which is very great," and, as a result, were "among the first houses" in Kingston. No doubt Taylor passed on "his list of planter clients" to McBean

\footnotetext{
${ }^{10}$ John Tailyour to Archibald McCall, Kingston, 20 June 1784, TFP, WCL, Letterbook 1781-5 ("selling" quote). For Tailyour's work as his cousin's town factor, see the correspondence within PLC, XIV; John Tailyour to Hercules Tailyour, Kingston, 7 June 1783, Ibid. ("Town" and "desirable" quotes). For the emergence of the commission system, see K.G. Davies, "The Origins of the Commission System in the West India Trade," Transactions of the Royal Historical Society, $5^{\text {th }}$ ser., 2 (Jan. 1952), pp.89-107. Tailyour did work as his cousin's attorney from May 1791 until May 1792, for which, see PLC, VANNECK-ARC/3A/1791/14-15; 1792/1. John Tailyour to George Carnegie, Kingston, 20 March 1784, Ibid. (“£700” quote). John Tailyour to Hercules Tailyour, Kingston, 21 February 1784/, TFP, WCL, Letterbook 1781-5 ("get into" quote).
} 


\section{Guinea Factors in Jamaica}

and Bagnold too, which, as Barry Higman points out, he inherited upon the death of his merchant father, rooting Tailyour's customer base in the early eighteenth century, when Patrick Tailzour first arrived in Jamaica. Simon Taylor also acted as security for his cousin's new firm, a connection Tailyour made clear to his customers by altering his surname upon the formation of McBean, Bagnold \& Taylor, something he had "reason to think ... might be of use to me \& knowing it could not do any harm," and to "pay a compliment to Mr T[aylor]." Tailyour's own "losses \& disappointments" from his American schemes put it "out of my power" to invest his own capital in the partnership, and so he turned to his mother's affluent cousins George and Sir David Carnegie MP, and his own brother Hercules, who lent him $£ 1,500$ to cover the costs of the wharves, stores, and liquid assets necessary to join the business. ${ }^{11}$

After seven years and five voyages crisscrossing the Atlantic in search of employment, John Tailyour had, by 1783, successfully established himself as a town factor in Kingston, aged twenty-eight. Family was key to his success. His father secured him an apprenticeship that gave him his education as a Virginian factor, and then his mother's family and his brother provided the necessary funds to start his factoring business and ride out the losses he sustained during his years traversing the Atlantic. Most importantly of all, Tailyour's distant cousin Simon Taylor treated him "like a father," and introduced him into the upper-tiers of the Kingston merchant community, giving him priceless connections that would be crucial to his start as a Guinea factor. Tailyour's

\footnotetext{
${ }^{11}$ For McBean and Bagnold, see John Tailyour to Hercules Tailyour, Kingston, 6 September 1783, TFP, WCL, Letterbook 1781-5; John Tailyour to John \& Alexander Anderson, Kingston, 6 September 1783, Ibid. ("have had" and "losses" quotes); John Tailyour to Charles Smith, Lyssons, Jamaica, 9 October 1783, Ibid. Higman, Plantation Jamaica, p.140 ("his list" quote). John Tailyour to Charles Smith, Kingston, 4 June 1784, TFP, WCL, Letterbook 1781-5 ("pay" quote). For Tailyour's acquisition of capital, see John Tailyour to Hercules Tailyour, Kingston, 21 February 1784, Ibid.; John Tailyour to George Carnegie, Kingston, 20 March 1784, Ibid. ("reason" quote); John Tailyour to Sir David Carnegie, 20 March 1784, Ibid. For Sir David Carnegie, see Sir Lewis Bernstein Namier and John Brooke eds., The House of Commons, 1754-1790 (London, 1964), p.485. For an example of the extensive property occupied by Kingston factors, albeit at a much later period, see "Plan and Elevations of the House, Stores and Wharf Belonging to Alexander Lindo Esquire," Kingston, 1805, TNA, MPH1-152; David Dick to John Tailyour, Norris, Jamaica, 6 September 1800, TFP, WCL, Box 2.
} 


\section{Guinea Factors in Jamaica}

early biography confirms what Randy Sparks recently observed in his study of Gold Coast African slave traders: "family was woven into the economic history of the [trans-Atlantic slave] trade." American slave traders in the late eighteenth century did not, as David Richardson and Robin Pearson have argued when considering the business of slave factoring, move away from "family or kinship" networks, to "less personal and more institutionalized arrangements for doing business," but appear to have used similar mechanisms as African slave traders to ensure trust and credit. $^{12}$

In December 1783, nine months after his arrival in Jamaica, Tailyour wrote to a British friend that "Guinea factorage is in my opinion one of the most profitable lines [in Jamaica]" and "in time I have hopes of getting some of it." Tailyour showed no compunctions to entering the slave trade, having apparently become comfortable with living in slave colonies, including short residences on his cousin's plantations where he hoped to become, as he described it, "part of a planter." During one such visit to the Lyssons estate sometime in 1784/5, Tailyour entered a relationship with Polly Graham, a mixed-race slave with whom he had four children. In 1790, Tailyour manumitted both Polly and her children but did not do so through some new found opposition to the slave system: the day after requesting the manumission of his family, Tailyour opened the sale the slaver Royal Charlotte, a timing that was probably not coincidental, as Jamaicans often bought "new negroes" to replace manumitted slaves. Later in life, Tailyour vehemently opposed abolition, and even participated in a Jamaican committee in support of the trade, indicating that he saw little wrong in

\footnotetext{
12 John Tailyour to John McKenzie, Kingston, 5 August 1783, TFP, WCL, Letterbook 1781-5 ("like" quote). Randy J. Sparks, "Gold Coast Merchant Families, Pawning, and the Eighteenth-Century British Slave Trade," $W M Q$, $3^{\text {rd }}$ ser., 70 (Apr. 2013), pp.318-9 ("Families" quote). Robin Pearson and David Richardson, "Social capital, Institutional innovation and Atlantic trade before 1800," Business History, 50, 6 (Nov. 2008), pp.766 ("less" quote), p.771 ("family" quote).
} 
the business. Tailyour's decision to enter the slave trade seems, then, to have been entirely profit motivated. $^{13}$

The lure of slave trading to men such as Tailyour is apparent when we compare the profits he could expect to earn from town and Guinea factoring. As a town factor, Tailyour had ships consigned to him from numerous correspondents in Newfoundland, Nova Scotia and, to a lesser extent, North America and Britain, bringing cargoes of lumber, flour or fish, amounting to from as little as $£ 50$ to as much as $£ 1,650$, but usually averaging around $£ 500$ Jamaican currency. Tailyour sold these cargoes either at market, or directly to his planter customers, and collected a five percent commission on the sales, and a seven-and-a-half percent commission on the return cargoes of, typically, sugar, rum and Spanish dollars. Tailyour therefore stood to earn, from a typical consignment of $£ 500$ worth of plantation stores, $£ 62.5$ currency in commissions. Tailyour also received commissions by selling sugar and rum on his planter customers' behalf, who used the proceeds to either purchase plantation stores from Tailyour, or to raise cash. In a typical transaction in September 1789, Tailyour sold ten hogsheads of sugar for $£ 279$ currency and collected $£ 14$ as a five percent commission. Thus, as a town factor, Tailyour transacted a large volume of business, and drew many small commissions that would, over time, amount to a large amount of profits. ${ }^{14}$

\footnotetext{
13 John Tailyour to John \& Alexander Anderson, Kingston, 14 December 1783, TFP, WCL, Letterbook 1781-5 (“Guinea" quote). John Tailyour to John \& Alexander Anderson, Kingston, 9 October 1783, Ibid. For Tailyour's request to manumit his family, see John Tailyour to Simon Taylor, Kingston, 3 January 1790, PLC, XIV/50. Tailyour's children were James (born 28 August 1786), Simon (b. 11 October 1788), John (b. 31 October 1790), and Catherine (b. 22 September 1792), all of whom were baptized (Livesay, "Children," pp.70-71). Two Reports from the Committee of the Honourable House of Assembly of Jamaica ... on the Subject of the SLAVE-TRADE (London, 1789) (London, 1789), pp.15-16. For Tailyour's opinions on abolition see, for example, John Tailyour to John \& Alexander Anderson, Kingston, 27 April 1788, 7 September 1788, 9 August 1789, 13 September 1789, TFP, WCL, Letterbook 1788-9.

${ }^{14}$ Tailyour's letterbook for 1786-7 is not extant, and so the analysis of Tailyour's American consignment business is based on the letters he wrote to the consignees in his letterbook covering the period 1788-9. During that period he received twenty-seven consignments, the majority of which came from Shelburne and Halifax (TFP, WCL, Letterbook 1788-9). A pound sterling was worth 1.4 Jamaican pounds. The sugar sale is taken from John Tailyour Account
} 
As a Guinea factor, by contrast, Tailyour could earn extremely substantial commissions in the space of just a single sale, as the records of two large slaving vessels that sold their captive cargoes in Kingston in 1783/4 demonstrates. On 17 March 1783, two days before Tailyour arrival in Kingston, Robert \& Thomas Hibbert sold 497 captives arriving on the ship Harlequin for $£ 29,287$ Jamaican currency, and collected $£ 1,426$ Jamaican currency as their a five percent commission of. In December 1784, while Tailyour was actively trying to enter the Guinea factor business, Rainford, Blundell \& Rainford sold 493 captives from the Golden Age for $£ 28,301$, and reaped $£ 1,395$ in commission from the sale. When the planters came to settle their debts arising from the sales, both firms would have also received an additional five percent commission on the remittances, returning, in total. Thus, both sales returned around $£ 3,000$ currency in commissions, equivalent to approximately fifty consignments of plantation stores from North America, or two thousand hogsheads of sugar sold at market. Guinea factoring was, as one British merchant told his partner in Jamaica in 1761 , "the only way to enrich you \& make you close your days in England." 15

To access the profits of the Guinea trade, Tailyour needed to know the credit-worthiness of individual planters, to whom he would lend sizeable sums when making slave sales. When a ship arrived in Kingston the Guinea factor issued the captain a set of bills of exchange drawn on a British banker, known as a "guarantee," for the proceeds of the sale. He then gave credit to each planter for the value of the slaves they had purchased, creating a string of debts owed to him in

\footnotetext{
Journal, 1789, TFP, WCL, Box 7. For the commissions on plantation stores, see for example, John Tailyour to Thomas Christie \& Sons, Kingston, 2 October 1784, TFP, WCL, Letterbook 1781-5.

${ }^{15}$ Accounts and Invoices of the Ship Golden Age and Harlequin, Stanley Dumbell Papers (hereafter SDP), University of Liverpool Library (hereafter ULL), GB141 MS.10.48. For the profits to be earned by Guinea factoring, see also Smith \& Baillies to Henry Bright, St. Kitts, 21 June 1763 in Morgan ed., Bright-Meyler, pp.373-4; Richard Meyler to Jeremiah Meyler, Bristol, 28 April 1761 in Ibid., p.365 ("enrich" quote); David Duncombe to Lowbridge Bright, Kingston, 19 June 1790 in Ibid., pp.546-7.
} 


\section{Guinea Factors in Jamaica}

Jamaica that he hoped to recoup before his own bills in Britain became due. If he sold several ship loads of slaves, Tailyour's outstanding debts could thus reach hundreds of thousands of pounds, astronomical sums that tested even the most extensive fortunes. Factors who did not know the financial circumstances of the planters could find themselves holding bad debts, while their own obligations stood due in Britain, a situation that could lead to bankruptcy. Tailyour had an advantage in that he had inherited his cousin's network of reliable planter friends, which he further cultivated through his own factoring business, and was very aware of the risks of bad planter debts, having seen his Virginia company collapse as a result of outstanding debts. In May 1784, for example, he wrote to a British slaving merchant that from the "extent of Mr Taylor's connexion [sic]," he could sell three or four shiploads of captive Africans per year (approximately twelve hundred people) "without being obliged to run any risque [sic] of bad debts." Tailyour used his cousin's carefully crafted web of clients to substantially reduce the risks of the slave trade. ${ }^{16}$

In addition to a network of credit-worthy planters in Jamaica, Tailyour needed a complementary network of British slave-traders who would consign their ships to him. He faced a difficult task, however, because as he later put it, "Every Guinea Ship that arrives here is particularly addressed to some house." Liverpool slave trading firms-who controlled approximately seventy percent of Britain's slave trade throughout the late-eighteenth centuryhad particularly close connections to Jamaica-based agents dispatched from their own town (Table 2). Thomas Aspinall, who vended 13,586 Africans between 1785 and 1796, received slave ships almost exclusively fitted out by Liverpool companies including his sister firm Gregson, Case \&

\footnotetext{
${ }^{16}$ For the trans-Atlantic credit system, see Kenneth Morgan, "Remittance Procedures in the Eighteenth-Century British Slave Trade," The Business History Review, 79, 4 (Winter, 2005), pp.735-9. John Tailyour to John \& Alexander Anderson, Kingston, 6 May 1784, TFP, WCL, Letterbook 1781-5 (“extent” quote). For the reliability of Tailyour's customer base, see also John Tailyour to Thomas Jones, Kingston, 17 February 1788, TFP, WCL, Letterbook 1788 9; John Tailyour to John Anderson, Kingston, 7 September 1788, Ibid.; John Tailyour to William Miles Jr., Kingston, 15 September 1789, Ibid.
} 
Aspinall. Rainford, Blundell \& Rainford sold 11,698 captives arriving on Liverpool vessels alone in the same period, especially those of William Boats, one of Liverpool's premier slaving merchants. Jonathan Blundell Junior, the firm's Liverpool based partner, implied that Liverpudlian factors obtained the consignment of slave ships through the close interlacing of family and merchant networks: Boats had been unusually "shy and unfriendly" to their company, Blundell wrote, because of "difficulty between the young females of [the Boats and Blundell families]," and so he expected Boats to be "unsteady" in sending his ships to Rainford in Kingston. Throughout his time as a Guinea factor, Tailyour faced competition from numerous Liverpool slaving firms with agents in Kingston, which effectively closed off the majority of Britain's transAtlantic slave trade to his company. ${ }^{17}$

\section{Insert Table 2 here}

Without access to Liverpool ships, Tailyour tried to obtain support from merchants in London and Bristol, the second and third largest British slaving ports. In February 1784, Simon Taylor again exerted himself on Tailyour's behalf by asking William Miles, a Bristolian sugar magnate, to act as the guarantee for his cousin's company. Miles had travelled in his youth from his native Hertfordshire to nearby Bristol, where he undertook a carpenter's apprenticeship, a position he used to gain passage to Jamaica. By shrewdly trading sugar between Bristol and Jamaica, Miles built his fortune, obtaining at the same time connections to the island's planters, including Simon Taylor, who managed his Golden Valley plantation. Miles cemented his place as one of the leading sugar merchants in Bristol through active participation in local politics and a

\footnotetext{
${ }^{17}$ John Tailyour to William Miles Jr., Kingston, 22 November 1789, TFP, WCL, Letterbook 1788-9 ("every" quote). For a detailed analysis of the Rainfords' connections to Liverpool merchants, see Haggerty Merely for Money, pp.1791. Jonathan Blundell Junior to Rainford, Blundell \& Rainford, Liverpool, 4 June 1787, LRO, PEC, 920 CHA/1 ("shy" quote).
} 


\section{Guinea Factors in Jamaica}

strategic marriage into the upper echelons of Bristolian society. When Simon Taylor asked Miles to act as the financial backer for his cousin's Guinea factoring firm in 1784 , he accepted to "shew my gratitude to my friend Mr Simon Taylor," and waived the customary half percent fee charged by guarantees for accepting bills of exchange, a favor that Taylor reciprocated by not charging an attorney's fee for the management of Golden Valley and promising to act as security for his cousin's debts. ${ }^{18}$

In acquiring a British backer directly connected to the Jamaican plantation complex, Tailyour mirrored other leading Kingston Guinea factoring companies, each of which derived their capital from the West India trade and, in some cases, the direct slave trade. Alexandre Lindo drew bills for slave sales upon his own brokerage firm Lindo, Lake \& Aguilar, a London house with close connections to the partners' network of Jamaican plantations and, through the Lake family, the Liverpool slave trade. William Daggers relied on his brother-in-law Moses Benson, a ship captain cum town factor who "amassed a handsome fortune" in Jamaica during the 1760s and 1770s, before shifting his fortune into sugar-brokerage and slave ships in Liverpool. Rainford, Blundell \& Rainford drew their bills on Jonathan Blundell Senior, a Liverpool merchant with "good connections in Jamaica, having imported sugar and rum from there since at least 1763," who invested heavily in the direct slave trade until 1780, after which he put his capital behind his son's factoring firm. Other firms had backers who drew their capital solely from the West India trade. The Hibbert family company, responsible for the sale of 16,254 slaves prior to the American War, and returnees to Guinea factoring in the late 1780s, were sponsored by their sister firm in

\footnotetext{
${ }^{18}$ For William Miles, see H.R. Fox Bourne, English Merchants, 2 (London, 1866), pp.16-7; Kenneth Morgan ed., "Calendar of correspondence from William Miles, a West Indian merchant in Bristol, to John Tharp, a planter in Jamaica, 1770-1789," in P. McGrath ed., A Bristol Miscellany (Bristol, 1985), pp.82-3. William Miles to John Tharp, Bristol, November 1785 in Ibid., p.110 ("shew" quote). John Tailyour to John \& Alexander Anderson, Kingston, 19 October 1788, TFP, WCL, Letterbook 1788-9.
} 
London, one of the largest West India houses in Britain, which never directly invested in slave ships. William Miles likewise never purchased shares in slaving vessels, but still participated in the slave trade by putting his wealth, derived from the sugar trade and his plantation, behind Tailyour's firm. The labor of enslaved Africans, which supported the capital of guarantors like Miles, therefore drove around a vast trans-Atlantic "wheel" of commerce in which bills from slave sales were used to finance slave ships fitted out from Britain, bringing more captives to the colonies. $^{19}$

Tailyour utilized his new Bristol connection to try and obtain consignments of slave ships. In December 1783 and May 1784, he expected the ships Mary and Africa to come to him, but he was disappointed when both ships landed their captives in Saint Vincent instead. In July 1785, he received the first two slave ships to his new company, the Diligence and Hornet, neither of which led to any further consignments from the owners, who were both minor investors in the slave trade. Fifteen months later, Tailyour terminated his partnership with McBean and Bagnold and become a sole trader, taking his cousin's business with him. In September 1787, Simon Taylor wrote to James Jones, by then Bristol's principal slave trading merchant, presumably advertising the creditworthiness of his cousin's new company, who three months later, sent his ship King George to Tailyour. In June 1788 and January 1789, William Miles also convinced the Bristol merchants Thomas Jones and John Anderson to order their ships Wasp and Alert to Tailyour's address. With links to three of Bristol's premier slave trading merchants and his bills guaranteed by a leading

\footnotetext{
${ }^{19}$ For Lindo, see Ranston, Lindo Legacy, pp.48-9; Taylor Ballantine \& Fairlie to John Tailyour, Kingston, 10 December 1792, TFP, WCL, Box 6. For Benson, see J.A. Picton, Memorials of Liverpool: Historical and Topographical, 2 (Liverpool, 1875), pp.274-5 (“amassed" quote). For Blundell, see Haggerty, Merely for Money, p.180. For the Hibberts' trade, see Two Reports, pp.20-1. See also R.B. Sheridan, "The Commercial and Financial Organization of the British Slave Trade 1750-1807," The Economic History Review, New Ser., 11 (1958), pp. 254-5. Hamer et al. eds. Paper of Henry Laurens, VI, pp.88-89, Henry Laurens to Ross \& Mill, Charleston, 2 September 1768 ("wheel" quote).
} 


\section{Guinea Factors in Jamaica}

Bristolian sugar broker, Tailyour had, by 1789, emerged as the main Guinea factor for Bristol slave ships arriving in Kingston (Table 2). ${ }^{20}$

Tailyour contacted his own acquaintances to secure slavers from London. During his residence in Britain, he formed a close friendship with Scottish merchants John and Alexander Anderson, nephews of Richard Oswald, the owner and operator of the Bance Island slave factory in the Sierra Leone River. Oswald and his Scottish "associates" had operated their integrated slaving company throughout the 1770 s, but had all but ended their business during the American War when a French naval squadron demolished the Bance factory. Failing to find a buyer before Oswald's death in 1784 , the title to the factory, along with a $£ 10,000$ inheritance, passed to his nephews the Andersons, who repaired the facility and began to dispatch slave ships to the coast and then to John Tailyour, the first of which, the Concord, arrived in December $1789 .^{21}$

By 1789, Tailyour had constructed a network of three Bristol, and one London merchant houses, who could dispatch shiploads of captive Africans to him, marking his emergence as one of Kingston's leading Guinea factors. The importance of this network to Tailyour's business can be seen in the number of slave ships that he had addressed to him before and after 1789. From 1783 until 1788, he had sold captives from just four vessels, making him one of Jamaica's smallest

\footnotetext{
${ }^{20}$ For the Mary, Africa, Diligence, and Hornet, see John Tailyour to John \& Alexander Anderson, Kingston, 14 December 1783, TFP, WCL, Letterbook 1781-5; John Tailyour to John \& Alexander Anderson, Kingston, 6 May 1784, Ibid.; John Tailyour to John \& Alexander Anderson, Kingston, 8 July 1785, TFP, WCL, Letterbook 1781-5. For the dissolution of McBean, Bagnold \& Taylor, see John Tailyour to Angus McBean \& Thomas Bagnold, Kingston, 20 August 1786, TFP, WCL, Box 6; Angus McBean \& Thomas Bagnold to Simon Taylor, Kingston, 26 August 1786, Ibid.; Simon Taylor to Angus McBean \& Thomas Bagnold, Hutters River, Jamaica, 30 August 1786, Ibid. McBean \& Bagnold begged Taylor not to take all of his business from them, given that it was "so material a part of our dependence," but Taylor coolly informed them that Tailyour was his only relative in the island, and hence more deserving of it. For the Bristol slave traders, see David Richardson, Bristol, Africa, and the Eighteenth-Century Slave Trade to America, 4 (Bristol, 1996), pp.xxi-xxii.

${ }^{21}$ John Anderson of London, who was unrelated to his namesake in Bristol, had a background that closely mirrored John Tailyour's, having moved to the Chesapeake from Glasgow as a tobacco factor in 1775, before returning to London as a merchant. Tailyour thus had numerous opportunities to meet Anderson (Hancock, Citizens of the World, pp.111-2, 172-220). For the Anderson's inheritance, see John Tailyour to John \& Alexander Anderson, Kingston, 26 December 1789, TFP, WCL, Letterbook 1788-9.
} 
dealers in enslaved Africans. In the same period, he had imported large quantities of plantation goods, almost certainly amounting to more than the value of the 1,367 captives he had sold into slavery. In 1789 alone, by contrast, Tailyour sold 1,740 African captives from six different slave ships - all of them from his new group of British merchants - pushing him ahead of the ten other Jamaican factoring firms selling slaves during that year (Table 3). In the following year, he slightly shrank his investment in the trade, selling four ship-loads of captives, and four more in 1791, all from his usual British clients. For the first five years of his career in Jamaica, Tailyour was a town factor. From 1789 onwards, Tailyour was both a Guinea and town factor.

\section{Insert Table 3 here}

Tailyour's multiple combination of Guinea and town factoring is clear from his letters, account books and newspaper advertisements. He reported in July 1789 to a Scottish merchant that he was "considerably concerned in the Factorage business," and had "a good many Consignments from America, principally Nova Scotia," in addition to a "wharf \& Lumber business" that he operated in partnership with Peter Ballantine and James Fairlie, two other Scottish Kingston merchants. All of these "different lines of business" afforded Tailyour "full employment." In January and February 1790, The Daily Advertizer briefly reported shipments of plantations stores consigned to merchants in Kingston. In that two-month period, eleven vessels came to Taylor, and eleven to Ballantine and Fairlie, carrying fish, wood, oil, shingles, salt, and vegetables. When his two business are combined, Tailyour was Kingston's largest town factor, at least for the short period reported. Ascertaining the full extent of Tailyour's town factoring business beyond September 1790 is difficult because of a paucity of account books in his papers, but there is ample 


\section{Guinea Factors in Jamaica}

evidence within his correspondence that he carried on importing large quantities of plantation stores throughout his career, while simultaneously selling captives. ${ }^{22}$

Newspaper advertisements and the extant sales books of other Guinea factoring firms show that Tailyour's strategy of selling plantation stores alongside captive Africans was typical. Of the twelve Kingston Guinea factoring firms selling slaves in 1790, eight imported at least one cargo of plantation stores in the period reported by the Jamaica Daily Advertizer. At a much earlier date, the Kingston firm Case \& Southworth, made thirteen slave sales and 111 sales of plantation stores between 1754 and 1758. Austin \& Laurens, a Charleston, South Carolina company whose sales are recorded between 1750 and 1758, made 134 sales, of which thirty-three were slave slaves, the rest comprising various miscellaneous goods. Each cargo of captives sold averaged $£ 20,946$ South Carolina pounds in gross returns, compared to just $£ 1,296$ for plantation stores. Despite the small number of slave sales made by both firms, captives still comprised seventy-five percent of Case \& Southworth's gross sales, and eighty-four percent of Austin \& Laurens', confirming that a relatively small number of slave sales eclipsed even sizeable town factoring operations. ${ }^{23}$

Guinea factoring was an extension of town factoring. By selling low-priced plantation stores, town factors could cultivate a network of Jamaican customers - what Tailyour's partners later called his "country interest"- prior to selling enslaved Africans at high prices and long credits. Moreover, Guinea factors used debts generated by slave sales to capture planters business for their town factoring operations. Almost every other Jamaican Guinea factoring firm therefore

\footnotetext{
22 John Tailyour to Malcolm Ross, Kingston, 12 July 1789, TFP, WCL, Letterbook 1788-9 (“considerably” quote). The Daily Advertizer, Kingston, 2 January 1790-20 February 1790. It is not clear why the Daily Advertizer ceased reporting the consignee after February 1790. The newspaper continued to report the cargoes imported until 11 October 1790 , and then only reported the name of the ship, its captain, and its port of origin.

${ }^{23}$ Ibid.; Case \& Southworth Papers, LRO, 380 MD 35; Sheryllynne Haggerty, "Liverpool, the slave trade and the British-Atlantic empire, c. 1750-75," in Sheryllynne Haggerty, Anthony Webster and Nicholas White eds., The Empire in One City? Liverpool's Inconvenient Imperial Past (Manchester, 2008), pp.17-34; Austin \& Laurens Account Book April 1750- December 1758, BRBML, GEN MSS VOL 184.
} 
developed its own "country interest" through town factoring. For example, Alexandre Lindo, Kingston's largest Guinea factor, began his mercantile career, his family's biographer writes, in the 1760s as "a retailer, dealing in every sort of commodity that could be bought cheap," extending "credit only to such parties whom he considered safe and commercially worthwhile," before moving into the slave trade in 1775. Similarly, former West India ship captain Samuel Rainford traded extensively in plantation stores and sugar before engaging in the Guinea factoring trade. However, the barriers to entering Guinea factor meant that the business was not open to all: of the thirty-six factoring firms that imported plantation stores in January and February 1790, twenty-six never had any involvement in the trans-Atlantic slave trade. ${ }^{24}$

In December 1783 Tailyour wanted to become a slave trader to obtain the substantial profits of Guinea factoring, but it was only five years later that he considered himself "as established in that Trade." Aspiring Guinea factors like Tailyour struggled to break into the slave trade because they first needed to craft two complimentary networks: one of trusted planters to whom they could sell slaves, and a second of British merchants who would consign slave ships. Neither objective was easy. Few men had connections to Jamaica's affluent and tightly-knit plantocracy; fewer still had connections to elite British slaving merchants. Even with his own priceless link to his cousin, it took Tailyour five years to cultivate the networks needed to provide him with a regular supply of slave ships, during which time he worked almost exclusively as a town factor, a common strategy among Kingston merchants. Given the barriers to entry, Guinea

\footnotetext{
${ }^{24}$ Taylor, Ballantine \& Fairlie to John Tailyour, London, 13 January 1793, TFP, WCL, Box 6 ("country interest" quote). Ranston, Lindo Legacy, p.37 ("retailer" quote); Haggerty, Merely for Money, pp.179-80. Other firms cultivated their country interest through the management of plantations, which they peopled with captives bought from the ships they brokered. See, for example, Alexander MacLeod to James Rogers, Spanishtown, Jamaica, 28 June 1790, James Rogers Papers (hereafter JRP), The National Archives, London, (hereafter TNA), C107/9; John Tharp to James Rogers, Trelawney, Jamaica, 28 December 1790, Ibid.; Karras, Sojourners, p.70.
} 


\section{Guinea Factors in Jamaica}

factoring was hence a near oligopoly, in which a small handful of well-established companies controlled the trade, and excluded newcomers. ${ }^{25}$

We can see how John Tailyour's two-pronged business strategy of forging connections in Jamaica and Britain worked in practice when we examine how Guinea factors sold slaves in Kingston, a process that largely remains a mystery at present. Abolitionists paid comparatively little attention to slave sales during their campaign, save to expose the "scramble sale," leaving historians few descriptive accounts. Tailyour's extensive correspondence, which is couched in the polite language of eighteenth-century business, likewise contains relatively little detailed information on the sales he conducted. To reconstruct slave sales we must hence draw on newspaper advertisements, slaving merchant accounts, plantation papers, ship books and records from the abolitionist debates, many of which derive from beyond the period of Tailyour's career. Given the size of the subject, the planters' demand for Africans of specific "ethnicity" will, however, be dealt with in a separate essay. $^{26}$

25 John Tailyour to John \& Alexander Anderson, Kingston, 18 August 1788, TFP, WCL, Letterbook 1788-9 ("established" quote). That a high concentration ratio was characteristic of Guinea factoring, rather than unique to Kingston in the period of Tailyour's career, is clear when we examine other colonies and time periods. Between 1766 and 1778 the top five Guinea factoring firms in Le Cap Francais, Saint Domingue, landed forty-four percent of the slaves. The two leading firms, Les Mesnier Freres and Stanislas Foache \& Company, engrossed twenty-seven percent of sales and relied on similarly compact networks as their Jamaican counterparts: the Mesniers drew vessels exclusively from Bordeaux and La Rochelle, whereas Foache had vessels consigned only from Saint Malo and Le Havre (Les Affiches Americaines, Le Cap Francais, 1766-1778). In South Carolina, five men handled thirty-five percent of sales, albeit over a much longer period, 1735-1775 (Record of the Public Treasurers of South Carolina, 1725-1776, South Carolina Department of Archives). In Barbados, 1751-5 the top five firms controlled sixty-three percent of the trade (CO28/30, TNA), and in Grenada, 1784-8, just two firms had fifty-five percent of slave-ships consigned to them (CO101/28, TNA).

${ }^{26}$ Although Tailyour's company sold fifty-five shiploads of captives, only four detailed sales records are extant, all of which are located in separate collections than the Tailyour papers. Research for this paper unearthed account books for seven slave trading voyages, the captives from two of which Tailyour sold (the Alert and Lovely Lass, in 1788 and 1789 respectively, "A Report of the Commissioners appointed to enquire into Losses which may have been sustained by Owners of Ships or Vessels engaged in the African Trade..." in American papers in the House of Lords Record Office (London, 1983), Reel 1789, ff.124-146). The account book for the Enterprize in 1794, is located in the Thomas Leyland papers (Merseyside Maritime Museum (hereafter MMM), DX/1732), and the sales record for the Sarah in 
Tailyour obtained consignments of captives by writing to his British correspondents and advertising the potential sales he could make for them in Kingston. He issued each merchant house a written "guarantee," which gave the British slaving captain the option to sell the cargo of captives with his firm. Tailyour in turn pledged that if he elected to sell the slaves, his firm would issue bills of exchange for the sale, and that these would be "guaranteed" by his banker William Miles, to whom the slaver captain would present the bills upon his return to Britain. British merchants, even those friendly to Tailyour, accepted a number of these reports and guarantees from firms scattered across the Americas and even within Jamaica itself, and weighed up the decision to send their vessels to Tailyour against the potential for sales in other American ports. If they decided that Tailyour's house could offer the highest slave prices and shortest terms of credit, they then wrote to him, detailing the month when their slave ship should arrive, the number of slaves it would carry, and the region of the African coast from which the ship had departed. ${ }^{27}$

While Tailyour wrote to merchants in his British network, he simultaneously conversed with planters within his Jamaican network about the captives they sought. Insight into the planters' decision making process appears in the diaries of Nathanial Phillips, a planter and former Kingston merchant with estates adjoining Simon Taylor's in Saint-Thomas-in-the-East. From 1776 until 1789, when he permanently left Jamaica for Britain, Phillips calculated whether he needed new workers. He then contacted his Kingston factor to, as he wrote in 1776, "let me know when any

1793, are lodged in the James Rogers Papers (TNA, C107/59). There are forty-nine other slave sale accounts for lateeighteenth-century Jamaica, of which eighteen fall in the period 1785-96.

${ }^{27}$ For the anticipation of arriving ships, see for example, John Tailyour to John \& Alexander Anderson, Kingston, 6 May 1784, TFP, WCL, Letterbook 1783-5; John Tailyour to James Jones, Kingston, 15 February 1789, TFP, WCL, Letterbook 1788-9; John Tailyour to John \& Alexander Anderson, Kingston, 12 July 1789, Ibid.; John Tailyour to William Miles, Kingston, 22 November 1789, Ibid.; John Tailyour to John \& Alexander Anderson, Kingston, 18 October 1789, Ibid.; John Tailyour to James Jones, Kingston, 22 November 1789, Ibid.; John Tailyour to Camden, Calvert \& King, Kingston, 16 May 1790, TFP, WCL, Letterbook 1790-2. For British merchants' decision making process, see Stephen D. Behrendt, "Markets, Transaction Cycles, and Profits: Merchant Decision Making in the British Slave Trade," WMQ, 3rd Ser., 58 (Jan. 2001), pp.171-204. 
Negroes arrive that will answer my purpose.” Although Tailyour did not deal with Phillips he must have had similar discussions with other calculating planters because he frequently informed British slave traders that he had numerous customers lodging orders for captives prior to the arrival of slave ships. In January 1789, for example, Tailyour encouraged William Miles to exert himself in securing slave ships because "I have told all my friends they must depend on my being able to supply them with Negroes this Spring." 28

When a slaving vessel arrived at Kingston, the captain went ashore and called on Tailyour, who boarded the vessel, examined the captives, and offered terms of credit, a figure that would ultimately decide whether the captain elected to sell with Tailyour. Tailyour then elected the best day to open the sale, striking a macabre balance between the need to increase the more healthy slaves' value by reviving them on fresh provisions, while substantial numbers of their exhausted and emaciated shipmates passed away. Between 1786 and 1788, for example, five percent of the 7,873 slaves imported by Alexandre Lindo died either before or during sale, close to the eight percent mortality suffered by slaves during the Middle Passage to Jamaica. J.B. Moreton, who lived in Jamaica during the 1780s, wrote in his critical account of the colony that "the dead bodies" were "concealed in the hold until night," and then thrown into the harbor, "least any report should circulate of the cargo's being sickly." Kingston factors opened sales, on average, thirteen days after a ship's arrival, a date set sufficiently far enough in the future that "every person in the country who wishes to purchase may have time to come to the sale," as Tailyour wrote in January 1789. Tailyour also spoke to other Guinea factors, read the newspapers, and then tried to time the opening

\footnotetext{
${ }^{28}$ For planters lodging orders for slaves in advance, see, John Tailyour to William Miles, Kingston, 17 August 1788, TFP, WCL, Letterbook 1788-9; John Tailyour to William Miles, Kingston, 12 April 1789, Ibid.; John Tailyour to William Miles, Kingston, 16 May 1790, TFP, WCL, Letterbook 1790-2; John Tailyour to James Jones, Kingston, 25 July 1791, Ibid. Diary of Nathanial Phillips, 1776, Jamaican Material in the Slebech Papers (hereafter JMSP), British Records on the Atlantic World, 1700-1900 (West Yorkshire, 2004), 9405 ("let" quote). John Tailyour to William Miles Jr., Kingston, 4 January 1789, TFP, WCL, Letterbook 1788-9 ("I have" quote).
} 


\section{Guinea Factors in Jamaica}

of his sales so that they did not clash with that of other vessels. Sales opened on every day of the week except Sunday, but most frequently on a Monday, presumably to give the maximum amount of time between the opening of the sale and the following Sunday. Having chosen a sale day, Tailyour had an advertisement inserted in newspapers and mailed letters and printed handbills to his expectant customers, informing them of the date of the sale, the name of the ship, and the number, ethnicity and regional origin of the captives, a surviving example of which is contained in his cousin's papers (Figure 1). ${ }^{29}$

Insert Figure 1 here

Historians have found that slave sales in the Americas occurred by different methods. Auctions rarely occurred for captives newly imported from Africa, except for small numbers of slaves who were left unsold at the end of sales. Rather, factors sought to dispose of an entire captive cargo as quickly as possible. One method was the infamous "scramble," recently identified by Sean Kelley as occurring in mid-eighteenth-century South Carolina, in which every purchaser simultaneously rushed into the yard at a given signal and seized whoever was available. Another

\footnotetext{
${ }^{29}$ For Lindo's sales, see Two Reports, p.25. The mortality of captives suffered by captives on the Middle Passage to Jamaica from 1786 to 1788 is taken from the TASTD. J.B. Moreton, West India Customs and Manners... (London: 1793), p. 145 ("daily" quote). The period of time before factored opened sales is from an analysis of 367 slave sales advertised in the Jamaica newspapers between 1775 and 1807 (The Kingston Journal, Kingston, 26 August 1789; The Daily Advertizer, Kingston, 1790, 1802; The Royal Gazette, Kingston, 1 January 1793- 30 June 1793, 1794, 1795, 1796; The Kingston Mercantile Advertizer, Kingston, 1802; The Cornwall Chronicle, Montego Bay, 1776-1794). Information for several later and earlier voyages was also drawn from merchant correspondence, both Tailyour's, and other slave trading merchants'. 111 sales opened on Monday; 62 on Tuesday; 59 on Wednesday; 61 on Thursday; 60 on Friday; and 14 on Saturday. Only twenty sales opened on an identical day to another slave ship in the same harbor. Holidays, poor weather, or the outbreak of diseases delayed some sales. Kingston factors opened their sales significantly later than their counterparts in Saint Domingue where sales opened, on average, just seven days after a ship's arrival in the period 1765-1778 (Based on 248 slave sales reported in Les Affiches Americaines). The Lovely Lass' sale account includes an entry for "Hand Bills and advertising sale in 4 news papers" ("Report of the Commissioners," f.482) and the Golden Age's included expenses for "advertising sale of Negroes, printed hand Bills, and Postage of Letters sent into the Country to advise of the day of sale" (SDP, ULL, GB141 MS.10.48, ff.27-8). Phillip Waldeck, a Hessian chaplain who witnessed a slave sale in January 1779, wrote in his diary that a town-crier went through Kingston on the morning of the sale distributing the hand-bills (Phillip Waldeck, A Hessian Report on the People, the Land, the War, As Noted in the Diary of Chaplain Phillip Waldeck (1776-1780), Bruce E. Burgoyne trans., (Westminster MD., 1995), pp.104-5).
} 


\section{Guinea Factors in Jamaica}

sale method, outlined by Burnard and Morgan in their broad study of the Kingston slave market between 1655 and 1788, occurred by a diametrically opposed method: "slaves were usually not sold by scramble or auction," they argue, "but by careful negotiation between astute, experienced and knowledgeable buyers and well-informed sellers." Rich buyers seeking a "small number of higher quality slaves," they write, "entered the sale at the beginning, leaving established buyers wanting larger parcels of Africans to buy slaves later on." In both arrangements the sale was open to all buyers who wanted slaves, with the ferocity and speed of the planters dictating the conduct of the sale in the scramble, and the purchasing power of the buyers during carefully negotiated sales. $^{30}$

The scramble certainly occurred in Kingston, but only when the demand for captives was sufficiently high enough to draw enough buyers to the opening day of the sale. In 1772, for example, Guinea factor Thomas Hibbert informed Nathaniel Phillips that at a recent slave sale he "really expected one half of the white people on board would have been trod to Death by the other half" in the rush to grab slaves. Eleven years later, when slave ship surgeon Alexander Falconbridge witnessed a scramble sale at Kingston, the demand for captives had reached such a fever pitch that 503 captives imported in the ship Golden Age were sold in just two days. In May 1790, Phillips heard from his attorney that slaves arriving recently had been "taken up with great scrambling." The Royal Gazette reported three years later that Alexandre Lindo has sold an entire

\footnotetext{
${ }^{30}$ Kelley, "Scrambling," pp.1-21. For the scramble, see Alexander X. Byrd, Captives \& Voyagers: Black Migrants Across the Eighteen-Century British Atlantic World (Baton Rouge, 2008), pp.59-61; Marcus Rediker, The Slave Ship: A Human History (London, 2007), pp.152-3. Burnard and Morgan, "Dynamics," pp.217 ("usually" quote). For sale procedures in the seventeenth century, see Galenson, Traders, Planters and Slaves, pp.71-92; Smallwood, Saltwater Slavery, pp.172-3.
} 


\section{Guinea Factors in Jamaica}

ship-load of slaves in just four hours, presumably by the scramble. Even the pro-slavery Jamaican planters William Beckford and Bryan Edwards acknowledged that the scramble occurred. ${ }^{31}$

When conducting a scramble sale, Tailyour and the ship captain separated the slaves into two different categories: "prime" and "refuse." "Prime" slaves were young men and women in good health and free from blemishes or injuries. The "refuse" captives, by contrast, were the sickly, old or very young remaining after the "prime" had been selected, or as the abolitionist James Ramsay, who visited slave sales in Saint Kitts during the 1770s, vividly described them those who were "emaciated, and unable to support themselves." This process of dividing the slaves into two categories occurred elsewhere in the British Americas. James Ramsay, whose brother-in-law was a Guinea factor, recollected that agents in Saint Kitts grouped slaves "into three sets; the healthy, well assorted, or prime slaves; the puny and ill-assorted; and the emaciated, sickly or refuse Slaves." Ramsay stated that the captives were then further sifted into two categories, the captain "endeavour[ing] to get as many of the puny, ill-assorted Slaves included in the [prime] as he can, the Factor to throw out as many as possible." Sean Kelley found that a similar division of captives occurred in South Carolina. After their division, the captives were shaved, glossed with oil, and their sores and blemishes concealed by the ship surgeon. ${ }^{32}$

\footnotetext{
${ }^{31}$ Thomas Hibbert Junior to Nathanial Phillips, Kingston, 20 August 1772, JMSP, 9212 ("really" quote); Accounts and Invoices of the Ship Golden Age, SDP, ULL, GB141 MS.10.48, ff.27-8. Falconbridge served as the surgeon on the Emilia, a vessel which landed its captives at Kingston ten months before the Golden Age (Alexander Falconbridge, An Account of the Slave Trade on the Coast of Africa, $2^{\text {nd }}$ ed. (London, 1788), pp.43-7; Richardson, Bristol, Africa, 3 , p.86); Thomas Barritt to Nathanial Phillips, Pleasant Hill, 29 March 1790, JMSP, 8355 ("indifferent" quote); The Royal Gazette, Kingston, 12 January 1793; William Beckford, Remarks on the Situation of Negroes in Jamaica... (London, 1793), p.7; Bryan Edwards, The History, Civil and Commercial, of the British Colonies in the West Indies, 2 (Dublin, 1793), p.115 ("slave ships" quote).

32 James Ramsay papers, Rhodes House, Oxford, MSS Brit. Emp.S.2, f.50 ("emaciated" quote). Report of the Lords of the Committee of Council for the Consideration of all Matters relating to Trade and Plantations (London, 1789), pp.141-2 ("into" quote). Kelley, "Scrambling," pp.6-7. For a disagreement over the selection of "prime" slaves, see John Tailyour to James Jones, Kingston, 15 February 1789, TFP, WCL, Letterbook 1788-9. Waldeck noticed that the factor assigned each captive a number prior to the sale, which was written on cards and hung around their necks (Waldeck, Hessian Report, p.105).
} 
Tailyour arranged the naked slaves on the opening day of the sale, placing the men and women in separate areas. Slave sales in Jamaica took place aboard the ship until 1 January 1789, when the Jamaica Assembly, under scrutiny by abolitionists, passed a new slave code which mandated that the factor use "a proper place or enclosure ashore, wherein the said slaves shall be sold," which were usually hired stores, known contemporarily as "Guinea Yards." Purchasers, some accompanied by their enslaved drivers, arrived immediately before the sale and approached Tailyour, who quoted them the fixed prices for "prime" slaves, which were staggered depending on the gender and "quality" of the slaves. ${ }^{33}$ In February 1789, for example, Tailyour divided the slaves from the ship Alert into ten different price categories: privilege men; cargo men; privilege men-boys; men-boys; and boys, with the corresponding five graduations for females. Each of the "qualities" of slaves was worth $£ 2$ Jamaican currency more than the next, with women worth $£ 2$ less than males in equivalent categories. Purchasers could accept the fixed prices and enter the sale, or leave, an interaction recorded by Thomas Thistlewood records in his diary: at ten o'clock in the morning on 12 August 1776, he boarded the slave ship True Briton in Savanna-la-Mar harbor with several other planters. He had hoped to pay $£ 55$ per slave, but the factor would not "abate off $£ 59$ " and so Thistlewood and "about a dozen" other purchasers left the sale. Nevertheless "others staid \& [the factor] sold a good many [slaves]." Those planters allowed into the sale would be only those willing to pay the prices the factor fixed for captives prior to the sale. ${ }^{34}$

\footnotetext{
${ }^{33}$ An Act to Repeal an Act, intitled, "An Act to repeal several Acts, and Clauses of Acts, respecting Slaves, and for the better Order and Government of Slaves, and for other Purposes (London, 1789), p.16 ("proper" quote). Kelly erroneously states that ship-board sales were banned in 1792 ("Scrambling," p.11). For instances of drivers attending sales, see Diary of Nathanial Phillips, 1786, JMSP, 9415; Diary of Thomas Thistlewood, 29 April 1765, MONSON/16; Waldeck, Hessian Report, p.105. The author of a guide to managing slaves advised that planters bring "a sensible negro" with them to the sale, of the same "country" as the slaves being purchased, who could speak to the captives and "determine whether they are really what they appear to be" (Dr. Collins, Practical Rules for the Management and Medical Treatment of Negro Slaves in the Sugar Colonies By a Professional Planter (London, 1803), p.45 ("Guinea Yards" quote).

34 "Report of the Commissioners," ff.137-9. Diary of Thomas Thistlewood, 12 August 1776, MONSON/27 ("abate" quote). Falconbridge wrote that in the scramble "all the negroes scrambled for bear an equal price; which is agreed
} 


\section{Guinea Factors in Jamaica}

Having negotiated terms with the buyers, Tailyour allowed them into the sale and, at a given signal, the "scramble" occurred. "[T] he doors of the yard were suddenly thrown open," Falconbridge recalled, "and in rushed a considerable number of purchasers, with all the ferocity of brutes." "It is scarcely possible to describe the confusion" he continued, "several of [the slaves], through fear, climbed over the walls of the court yard, and ran wild about the town." If the scramble sale was so chaotic, how then did Tailyour appease the planters within his network who sought out slaves for their estates? The price categories Tailyour established prior to the sale provides the answer. When dividing the slaves, Tailyour identified a number of "prime privilege" slaves who, according to a slave ship captain interviewed in July 1789, were the "picked slaves out of the prime amounting generally to eight or ten in the hundred." These slaves were sold at a premium of $£ 2$ Jamaican currency per person, and offered to certain planters as a "private choice." Tailyour restricted access to the "privilege slaves" to his closest associates. When Tailyour sold the Lovely Lass' captives in May 1789, for instance, he allowed sixty-one buyers to choose from 398 enslaved Africans, but designated twenty-one men and two women as "privilege prime," who he sold to eight of his friends, including his cousin Simon Taylor; Benjamin Turney, the doctor on one of Taylor's plantations, and his own factoring house. Numerous plantations papers record the purchase of "privilege" slaves, demonstrating that the practice occurred throughout Jamaica. Tailyour also aided his closest associates by, on rare occasions, allowing them to pick captives

upon between the captains and the purchasers before the sale begins" (Falconbridge, Account, p.44). For a similar division and pricing of the captives, see the sale accounts of the Golden Age in 1784 (SDP, ULL, GB141 MS.10.48, ff.27-8), Active ("Report of the Commissioners," ff.113-5); Chambres ("Report of the Commissioners," ff.342-5); Diana (Ibid., ff.347-9); Flora (JRP, TNA, C107/5); Fly (JRP, TNA, C107/6); James ("Report of the Commissioners," ff.223-8); Jupiter (JRP, TNA, C107/59); Lovely Lass (Ibid., ff.477-482); and Ruby (JRP, TNA, C107/13), all of which landed their captives in Jamaica between 1789 and 1792. 


\section{Guinea Factors in Jamaica}

before the sale had even begun, a practice that infuriated planters left to choose from the remaining slaves. $^{35}$

Tailyour needed to extend credit to purchasers after the sale, and so he could turn away planters he thought un-creditworthy, further limiting access to slaves. Ascertaining the exact terms of credit issued to planters is difficult because of a paucity of accounts recording bonds paid by the planters. However, a pocket ledger kept by Guinea factor Robert Rainford, when crossreferenced with the sale records of the Golden Age, reveals that Kingston factors varied the terms of credit depending on the standing of the purchaser. Most buyers paid for captives with credits extending from one to six months, while larger purchasers received credits as long as three years. Factors probably negotiated these terms prior to the sale: Nathanial Phillips recorded in his diary the credit terms he could expect to receive at sales. Kingston factors were thus under no obligation to allow anyone into the slave sales, and had, as Tailyour put it in 1788 , the "power to choose purchasers." 36

\footnotetext{
${ }^{35}$ Falconbridge, Account, pp.44-5 ("doors" quote). Falconbridge's account is largely corroborated by the evidence of a former South Carolina Guinea factor (Testimony of George Baillie in Sheila Lambert ed., House of Commons Sessional Papers of the Eighteenth Century, 73 (Wilmington, DE, 1975), p.184); "Report of the Commissioners," ff.169 ("picked" quote), 477-482. Thomas Barrett to Nathanial Phillips, Pleasant Hill Jamaica, 18 June 1790, JMSP, 8358 ("private" quote). Phillips occasionally struck a favorable deal by which he would acquire "the privilidge or prime Negroes, at the same price with the Cargo" (Instructions to attorney, JMSP, 8864; see also Nathanial Phillips to Thomas Hibbert Jr., London, 3 August 1784, JMSP, Letterbook 1775-1792, f.62). For the purchase of privilidge slaves, see Diary of Thomas Thistlewood, 21 December 1772, MONSON/23; Malcolm Laing to William Philip Perrin, Jamaica, 23 March 1773, Fitzherbert Papers, Derbyshire Record Office (hereafter DRO), 16758; York Estate general accounts, 1790, The Gale-Morant Papers, British Records Relating to America in Microform (Wakefield, 1977), 3/E; Jamaica Ledger 1769-1774, Chisholm Papers, NLS, Mss.5478. For the picking out of slaves before the sale had opened, see Diary of Thomas Thistlewood, 15 July 1776, MONSON/27; Diary of Nathanial Phillips, 1778, JMSP, 9407; John Tailyour to Thomas Jones, Kingston, 17 February 1788, TFP, WCL, Letterbook 1788-9; John Tailyour to Simon Taylor, Kingston, 29 November 1791, PLC, XIV/84.

${ }^{36}$ Accounts and Invoices of the Ship Golden Age, SDP, ULL, GB141 MS.10.48, ff.27-8; Pocket Ledger of Robert Rainford 1779-1796, National Archives of Canada, MG54. For the varied credit terms given by factor, see also Austin \& Laurens Account Book April 1750- December 1758, BRBML, GEN MSS VOL 184. Diary of Nathanial Phillips, 1787, JMSP, 9417. John Tailyour to William Miles, Kingston, 17 February 1788, TFP, WCL, Letterbook 1788-9 ("power" quote)
} 


\section{Guinea Factors in Jamaica}

A price structure that placed the best slaves out of the grasp of lesser planters, coupled with Tailyour's ability to exclude undesirable purchasers, meant that the scramble sale in Jamaica was not, as Sean Kelley has proposed in his study of South Carolina slave sales, a method designed to allow rich and poor planters equal access to the best "quality" captives. Rich, credit-worthy planters could, through their standing with the factor, access the healthiest and strongest slaves, while poor un-creditworthy planters would be excluded at the door to the sale or left to choose from the "less valuable" captives placed in the lower "quality" categories. Factors quickly disposed of large numbers of captives to expectant buyers within their network through the scramble sale and simultaneously rewarded selected purchasers. ${ }^{37}$

When the demand for captives dropped off, owing to an influx of slaves, a scarcity of provisions, or warfare, Guinea factors conducted slave sales by a slower, more negotiated method. As Tailyour wrote in December 1789, “[w]hen slaves are plenty the planters make their own terms," removing the linchpin of the scramble sale: the factor's ability to set the prices in advance and select buyers. Instead, factors opened the sale to the small number of available buyers and allowed them to carefully choose captives, a method of sale identified by Burnard and Morgan during the 1760s and 1770s. In late 1794, for example, the simultaneous arrival of several thousand captives in Kingston, coupled with the worsening military situation in the Caribbean dampened the demand for slaves. On 25 November 1794, the slave ship Enterprize arrived in Kingston with 399 captives consigned to Tailyour's partners. Two weeks later, they opened the sale to just nine purchasers, compared to the sixty-one who had scrambled for the Lovely Lass' slaves five years earlier. Rather than accept fixed prices, as in the scramble, the few buyers paid prices for "prime" captives which varied from $£ 60$ to $£ 75$ Jamaican currency. By the end of the first day, only eighty-

\footnotetext{
${ }^{37}$ Kelley, "Scrambling," pp.16-17.
} 


\section{Guinea Factors in Jamaica}

three of the slaves had been sold, leaving 277 enslaved Africans unsold. On 20 December, Tailyour's partners informed him that they still had seventy-three of the Enterprize's captives “on hand," and although the demand from Jamaican planters was "very slack" there was a "good brisk foreign demand" and so they hoped to "get clear of them on favorable terms for ourselves." Even so, forty-seven of the Enterprize's captives languished for a further two weeks until they were almost all purchased in a lot by David Henriquez, a slave "retailer," for just $£ 44$ per person on 8 January 1795, closing the sale. All told then, many of the Enterprize's captives spent longer awaiting purchase (forty-five days) than they did on the Middle Passage (thirty-nine days). ${ }^{38}$

The methods used to sell captives in Jamaica can be seen on a spectrum, with the scramble at one end, when planter demand was at a height, and the slow negotiated sale of captives at the other end, when demand was at a low. Not every sale was at either extreme, and so in order to ascertain where a sale particular sale fell on this spectrum, we must pay attention to the specific historical context in which it took place. There were probably few scramble sales in Jamaica prior to 1789 , except in periods when the planters' demand was particularly high, such as in 1782-4 when the American Revolutionary War created a scarcity of captives. The onset of the abolitionist campaigns, ironically, both brought the scramble to public attention, and increased its frequency by pushing up the planters' demand for captives. In January 1790, Tailyour accurately linked abolitionism to the shifting demand for slaves: should gradual abolition take place, he opined, "Negroes will be in great demand \& sellers may make their own terms." If the campaign failed, he continued, "our demand will not be so great." From 1790 until mid-1792, slave sales appear to

\footnotetext{
${ }^{38}$ John Tailyour to James Jones, Kingston, 26 December 1789, TFP, WCL, Letterbook 1788-9 ("plenty" quote). The Royal Gazette, Kingston, 28 November 1794; Account book of the Ship Enterprize, MMM, DX/1732; Taylor, Ballantine \& Fairlie to John Tailyour, Kingston, 20 December 1794, TFP, WCL, Box 6 ("on hand" quote. For instances of similarly slow sales, see the Rodney (JRP, TNA, C107/59) and Jenny (Thomas Leyland Company account books, WCL), both of which occurred in June 1793, and the Earl of Liverpool, in November 1797 (SDP, ULL, GB141 MS.10.50, ff.22-3).
} 


\section{Guinea Factors in Jamaica}

have been conducted in a less frantic form than the scramble, owing in part to the failure of the abolitionists to pass bills in Parliament. Planter demand picked up again in late 1792 and early 1793, before plummeting with the onset of the French Revolutionary War, a state of affairs that persisted until Tailyour's retirement in 1796. While probably not the most common method used to sell slaves in Jamaica over the whole course of the late eighteenth century, Tailyour used the scramble to sell slaves in several years of his career $(1789,1792-3)$ and, in the other years, conducted slower, more negotiated sales. ${ }^{39}$

There was one commonality among Jamaican slave sales: regardless of the demand for captives prevailing upon a ship's arrival, rich Jamaican planters always selected the highest-priced "prime" captives first. Planters preferred to buy no slaves at all rather than spending money on sickly slaves, or as Tailyour put it in May 1788, "Planters in great credit buy none but prime slaves." During the sale of the Lovely Lass' captives in 1789 , for example, Tailyour wrote to the ship's owner that he had sold 321 slaves, but had 77 remaining, despite having had "purchasers enough for 7 or 800 slaves" on the opening day. "Had there been that number of prime people on board," he wrote "all would have been sold." The logbooks of the slave ships Gregson and Ranger, which landed their captives in Kingston in 1789 and 1790, show that those slaves who were not bought on the first day of the sale were re-landed at the store the next day, a process that was repeated until they were all sold. Meanwhile, the remaining slaves' "prime" shipmates could already be on their new plantations. In January 1790, for example, an African "girl with one eye" was "crying most dreadfully" in Tailyour's store, because her sister had been bought by Simon

\footnotetext{
${ }^{39}$ John Tailyour to William Miles, Kingston, 24 January 1790, TFP, WCL, Letterbook 1790-1 ("great demand" quote). For Tailyour's opinions on abolition, see John Tailyour to John \& Alexander Anderson, Kingston, 27 April 1788, TFP, WCL, Letterbook 1788-9; John Tailyour to John \& Alexander Anderson, Kingston, 7 September 1788, Ibid.; John Tailyour to John \& Alexander Anderson, Kingston, 9 August 1789, Ibid.; John Tailyour to John \& Alexander Anderson, Kingston, 13 September 1789, Ibid.; John Tailyour to John \& Alexander Anderson, Kingston, 6 April 1790, TFP, WCL, Letterbook 1790-2; John Tailyour to Simon Taylor, Kingston, 15 January 1792, PLC, XIV/85.
} 
Taylor and moved to one of his livestock pens two days earlier, at the opening of the ship Royal Charlotte's sale. ${ }^{40}$

Once the prime slaves had been sold to Jamaican planters, the remaining slaves were Tailyour wrote, "sold either to Jews who make a business of fattening them \& retailing them out singly or to Foreigners.” Drawing on a large sample of slave sales made in Jamaica between 1747 and 1807, Burnard and Morgan found that this trade occurred on a large scale, with Kingston merchants purchasing fifty-eight percent of all captives sold. No doubt many of these men were actually Kingston merchant-attorneys who purchased slaves and immediately dispatched them to plantations under their management. Nevertheless, Tailyour's papers confirm that captives were purchased in bulk both by "retailers," and visiting buyers from the neighboring colonies. After the arrival of the King George in 1788, for instance, Tailyour informed its owner that after selling the "prime" portion of the 415 captives to planters, he sold two lots of eighty slaves to large scale buyers, including Alexandre Lindo, who had strong connections with re-exporters of slaves. These large-scale buyers, Lindo excepted, almost always appeared after the first day of the slave sale, demonstrating that they consciously pursued a strategy of purchasing unhealthy slaves in bulk. Newspaper advertisements show that once purchased, captives were imprisoned in store houses, and offered for sale to planters. In July 1790, for example, Messrs Henriques \& Bravo, a Spanish Town firm, offered for sale 150 "prime" slaves, all of whom were kept in the company's presumably extensive store-cum-barracoon. The mortality rate suffered by emaciated and sickly

\footnotetext{
40 John Tailyour to James Jones, Kingston 30 May 1788, TFP, WCL, Letterbook 1788-9 ("Planters" quote); John Tailyour to James Jones, Kingston 31 May 1789, TFP, WCL, Letterbook 1788-9 ("purchasers" quote). For the planters' desire for "prime" slaves, see also John Tailyour to Simon Taylor, Kingston, 29 November 1791, PLC, XIV/84; John Tailyour to John \& Alexander Anderson, Kingston, 17 November 1791, JTP WCL, Letterbook 17901792; Dr. Collins, Practical Rules, p.83. Logbook of the Ship Gregson, TNA, HCA1/85; Logbook of the Brig Ranger, LRO, 387.MD.56. John Tailyour to Simon Taylor, Kingston, 6 January 1790, PLC, XIV/51 ("girl" quote). Upon the completion of the sale, Tailyour brought the slave ship captains to dine at his cousin's plantation, for which, see John Tailyour to Simon Taylor, Kingston, 19 December 1789, PLC, XIV/47; John Tailyour to Simon Taylor, Kingston, 27 June 1790, PLC, XIV/57.
} 


\section{Guinea Factors in Jamaica}

captives as they were nursed back to health so as to be later marketed as "prime" can only be guessed at, but must have been far in excess of their shipmates who were sold to planters. ${ }^{41}$

Other slaves were shipped off, legally or illegally, to the neighboring Spanish or French colonies, where higher slave prices could be obtained, even for weakly slaves ignored by Jamaican buyers. Foreign buyers sailed to Jamaica between November and March, hoping to purchase small numbers of captives with specie, and avoid the hurricane months. This trade was considerable: in 1795-1797, the Jamaica Assembly reported that one in every three slaves sold was re-exported. Captains in small vessels carried off groups of between thirty and fifty slaves, principally to Cuba and British occupied Saint Domingue, but also, remarkably, to Trinidad, twelve hundred miles to the southeast. At an earlier period, Kingston merchants also smuggled slaves into French Saint Domingue. In 1767, for example, Simon Taylor and his partner Robert Graham purchased "60 or $70 .$. sickly" slaves from an arriving slave ship and "sent them up" to Saint Domingue in a vessel sailing under foreign colors and using a system of signals to avoid the coast guard. Kingston factors also visited Saint Domingue to establish profitable connections with French merchants. When Nathaniel Cutting, an American slave trader, visited Saint Marc in July 1790, he dined with Alexander Shaw, one of the partners in Shaw \& Inglis, who had "commenced a Partnership with a House here to whom he has sent many Slaves." The profits, Shaw boasted, amounted to £28 Jamaican currency per captive and slave smuggling was, Cuttings wrote in his diary, "the most lucrative Business that a Commercial man can pursue." Two years later, Cutting learned from a

\footnotetext{
${ }^{41}$ John Tailyour to James Jones, Kingston 30 May 1788, TFP, WCL, Letterbook 1788-9 (“sold" quote). Falconbridge recalled that the remaining captives were sold to "Jews and surgeons, but chiefly the former, upon speculation" (Falconbridge, Account, p.43). Burnard and Morgan, "Dynamics," pp.222-3. John Tailyour to James Jones, Kingston 15 February 1789, TFP, WCL, Letterbook 1788-9. For Lindo's re-export trade, see Two Reports, p.25. For the Jewish population of Kingston, see Mordechai Arbell, The Portuguese Jews in Jamaica (Kingston, 2000); Faber, Jews, Slaves, pp.57-90; Long, History, 2, p.295. Kingston Daily Advertiser, Kingston, 2 July 1790. Henriques seems to have also kept a number of captives in a store in Kingston: on 7 March 1790, he advertised in the daily advertizer for four 'New Negro Men' who had runaway from his Kingston store. Henriques had purchased the captives 'six weeks ago' probably from a vessel arriving from the Windward Coast.
} 
merchant in Cap Francais that the slave trade to Cuba could be equally as profitable because captives could be sold at Havana for high prices, even if they were of a "secondary quality." Unhealthy captives could thus experience another traumatic sale in a distant island, or a retailers' yard, by virtue of the Guinea factor separating them out from their "prime" shipmates. ${ }^{42}$

The slave sales organized by John Tailyour and his fellow Guinea factors were thus important determinants of a captive African's fate after their arrival in the Americas. Through their contacts with British merchants, Guinea factors attracted ship-loads of African slaves, who they divided according to their health, and then pushed into migratory routes that meshed with their Jamaican networks. The healthiest "prime" slaves would be purchased first by the factor's expectant planter associates, sometime through the scramble sale. The remaining captives, by contrast, would be bought in bulk, and either retained in the island by "retailers," or shipped off through another potentially lengthy Middle Passage. This process was by no means haphazard: Jamaican factors received captives from known merchants and passed them to known purchasers. The forced migration of enslaved Africans was hence closely linked to the business decisions of the Guinea factors who sold them into slavery.

Suffering from ill health, John Tailyour departed Jamaica in July 1792 and ceased to conduct slave sales. Immediately before his departure he formed Taylor, Ballantine \& Fairlie (hereafter TB\&F) with his town factoring partners, who continued to sell captive Africans in Kingston throughout 1792-1796, one of the most volatile periods in the history of Jamaica's slave trade. In the opening

\footnotetext{
${ }^{42}$ For the seasonality of the re-export trade, see John Tailyour to John \& Alexander Anderson, Kingston, 9 August 1789, JTP, WCL, Letterbook 1788-1789. Journals of the Jamaica Assembly, 1797-1802, 10 (Kingston, 1810) pp.367372, 436. For Taylor \& Graham's slave smuggling, see Robert Graham to Samuel Bean, 6 September 1767 ("60" quote), 24 March 1767, GGP, NLS, Acc.11335/178. Nathaniel Cutting Journal, 9 July 1790 ("commenced" quote), 27 January 1792 ("secondary" quote), Massachusetts Historical Society.
} 


\section{Guinea Factors in Jamaica}

years of the decade, a booming sugar market, the threat of abolition, and the turbulence in the competing Saint Domingue sugar and coffee export market all combined to massively increase the number of captives being landed in Jamaica: between 1789 and 1793, the volume of the transAtlantic slave trade to the island almost tripled, from 10,200 to 27,919 - the largest number of captives ever landed in Jamaica in a single year. The almost simultaneous outbreak of the French Revolutionary War and an Atlantic wide credit crisis in 1793 caused a huge downward fluctuation in Jamaica's slave trade: by 1796, the year when Tailyour retired, the number of captives landed had plummeted to 9,621 . TB\&F took advantage of these fluctuations by selling captives from thirty-four different slave ships, a three-fold increase on his pre-1792 business making, in the process, Tailyour's fortune. ${ }^{43}$

Upon his return to Britain, Tailyour spent his time trying to increase his company's business by dealing directly with slaving merchants. As he travelled around England from his base in London, Tailyour would have encountered other absentee Guinea factors such as Jonathan Blundell, who worked in Liverpool on behalf of Rainford, Blundell \& Rainford; members of the London based Hibbert family; and, by 1795, Alexandre Lindo and his own partner James Fairlie. In October 1792, Tailyour journeyed to Bristol and found the town's principal slave trading merchants to be "Intoxicated with success" stemming from surging slave prices in the Americas and unwilling to send their vessels to Tailyour's partners, choosing instead to seek better terms

\footnotetext{
${ }^{43}$ Tailyour had originally intended to return to Jamaica after two years but, in March 1793, he engaged Mary McCall, the daughter of his former employer (John Tailyour to Simon Taylor, London, 6 March 1793, PLC, XIV/94). He left behind his mixed race family in Jamaica, for which, see Livesay, "Children," pp.70-71. For Tailyour's ill health, see John Tailyour to Simon Taylor, Kingston, 12 February 1792, PLC, XIV/86; The Cornwall Chronicle, Montego Bay, 22 January 1791. For Tailyour's partnership with Ballantine and Fairlie, see John Tailyour to James Jones, Kingston, 15 January 1792, TFP, WCL, Letterbook 1790-1792.
} 
from newly established factoring houses in Jamaica's out-ports. TB\&F therefore sold slaves from three vessels in 1792, making them one of Jamaica's smaller slave factoring firms (Table 3). ${ }^{44}$

In February 1793, a credit crisis, coupled with the outbreak of the French Revolutionary War, engulfed Britain's economy, striking in particular at slaving merchants and factors and exacerbating the volatility of the slave trade. A month later, Tailyour visited Bristol and met with a "much more civil" reception from the slaving merchants, who "regret[ted] ever having sent ships to some of the new [factoring] houses" and promised to dispatch their slaving vessels, then at sea, to Tailyour's house, which held an "undoubted guarantee” from Simon Taylor and William Miles. The credit crisis also opened up the previously closed Liverpool markets. In July 1793, Tailyour employed Edgar Corrie, a Scottish friend of Simon Taylor's with close connections to Liverpudlian merchants, to help him obtain the consignment of Liverpool ships, and personally visited the town in early 1794 . With the Liverpool factoring houses' security endangered by the credit crisis, the city's slave traders turned to Tailyour's company to sell their captive cargoes. ${ }^{45}$

The 1793 credit crisis thus gave Tailyour's partners in Jamaica a pick of as many slaving vessels as they cared to manage, making TB\&F briefly the largest Guinea factoring firm in the Caribbean, if not the entire Atlantic World. In 1793 and 1794, Tailyour's company sold 9,262 captives arriving on twenty-eight ships, a third of which were Liverpool vessels, and engrossed

\footnotetext{
44 Ranston, Lindo Legacy, p.50. John Tailyour to Simon Taylor, London, 6 November 1792, PLC, XIV/89 ("intoxicated" quote). The new houses were most likely Shaw \& Inglis and Allan White \& Company, both of whom began to land large numbers of slaves from 1792. John Tailyour to Simon Taylor, London, 3 April 1793, PLC, XIV/95.

45 John Tailyour to Simon Taylor, London, 6 March 1793, PLC, XIV/94 ("civil" quote). For the credit crisis and the security of Tailyour's house, see Francis Hyde, Bradbury Parkinson, and Sheila Mariner, "The port of Liverpool and the crisis of 1793," Economica, 18:72, (Nov. 1951), pp.363-378; TB\&F to John Tailyour, Kingston, 11 May 1793, TFP, WCL, Box 6; TB\&F to John Tailyour, Kingston, 10 August 1793, TFP, WCL, Box 6; TB\&F to John Tailyour, Kingston, 18 October 1793, Ibid. For Corrie's work as Tailyour's agent, see his correspondence in TFP, WCL, Box 2. For Liverpool merchants turning to Tailyour to consign their vessels, see the letters from: Hayhurst, Poole $\&$ Fletcher, TFP, WCL, Box 3; Thomas \& William Earle, Box 2; Tarleton \& Rigg, Box 6; Ralph Fisher, Box 2; Thomas Leyland, Box 3; Thomas Clarke, Box 2; John Hodgson, Box 3; Joseph Ratcliffe, Box 5; William Forbes, Box 2; and James Penny, Box 5.
} 


\section{Guinea Factors in Jamaica}

twenty-two percent of the entire Jamaican slave trade (Table 3). This huge extension in Tailyour's business placed heavy financial burdens on William Miles who, with his health failing from the strain, repeatedly entreated Tailyour not to sell any more slaves. Tailyour began to curtail his business in 1795, when he sold four ship-loads of captive Africans, while turning down numerous offers from British merchants to consign vessels to TB\&F. A year later, he retired from the business and sold his shares to his clerks David Dick and John McCall, who joined Tailyour's partners to create the successor Guinea factoring company Ballantine, Fairlie \& Company. ${ }^{46}$

Tailyour's career as a Guinea factor lasted just twelve years, but proved to be incredibly lucrative. In 1783, aged twenty-eight and newly arrived in Jamaica with just $£ 1,500$ as capital, he asserted that with the "friendship of dame fortune" he could become rich in just ten years by working as a Kingston factor. Fifteen years later, Tailyour calculated that he possessed $£ 81,937$ sterling, which he invested in landed property. In 1798 , he used $£ 16,355$ of this fortune to repurchase the Kirktonhill and Balmanno estates that his family had sold upon the death of his father twenty-one years earlier and, and $£ 16,800$ to acquire the neighboring Garvock estate. Tailyour lent a portion of his extensive fortune to his friends, and put the rest into government stocks and bonds, earning interest that enabled him to live out the remainder of his life as a country

\footnotetext{
${ }^{46}$ Given the collapse of the French slave trade, and the large number of captives being landed in Jamaica versus the other British American colonies, only factors in Brazil could have feasibly competed with Tailyour (Voyages). For Miles complaints and health problems stemming from his debts, see the bundle of letters from him and his son in TFP, WCL, Box 5. In 1796, after his withdrawal from TB\&F, Tailyour did guarantee Ballantine \& Fairlie's bills of sale for 377 slaves sold from the Roman Emperor. For that sale, and the transfer of Tailyour's business to Ballantine, Dick, McCall and Fairlie, see TB\&F to John Tailyour, Kingston, 8 May 1796, 22 May 1796, 31 August 1797, TFP, WCL, Box 6; John Tailyour to Simon Taylor, PLC, XIV/103-140, 152. Simon Taylor invested directly in slave ships with John Tailyour's brother Robert in 1799, for which, see Simon Taylor to Robert Taylor, PLC, XIII and Stephen D. Behrendt, "Human Capital in the British Slave Trade," in David Richardson, Suzanne Schwarz, and Anthony Tibbles eds., Liverpool and Transatlantic Slavery (Liverpool, 2007), pp.66-7. Simon Taylor died in Jamaica in 1813, aged seventy-three.
} 


\section{Guinea Factors in Jamaica}

gentleman, until his death in February 1815, aged sixty, and with a net worth of almost $£ 100,000$ sterling. ${ }^{47}$

Tracing this massive expansion in Tailyour's fortunes directly to the slave trade is difficult because his papers contain few detailed financial accounts for the period of his trading career, and he operated his town factoring business alongside his slaving operations. However, evidence within his correspondence points clearly to Guinea factoring as the source of his prosperity. In December 1793, after selling 2,738 captives in a year, Peter Ballantine wrote to John Tailyour to report that the profits from TB\&F for the year would amount to approximately $£ 20,000$, of which Tailyour would receive half as majority share-holder. Assuming that each captive sold for an average $£ 48.9$ at a ten percent commission, slave trading made up $£ 13,389$ or sixty-seven percent of these returns. Tailyour later calculated that in the three years from 1794-1796, TB\&F earned profits of $£ 49,428$, of which he collected $£ 12,357$, having sold half of his shares to his clerks. In the years 1793-1796, when TB\&F imported 11,421 African slaves, Tailyour thus personally accrued $£ 22,357$ sterling in profits, a sum that must be added to the sizeable returns he made in the years 1785-1792. In 1790, for example, an envious Kingston factor estimated that Tailyour was earning "at least five or six thousand [pounds] a year" from the slave trade. Slave trading made John Tailyour's fortune. ${ }^{48}$

\footnotetext{
47 Tailyour's wealth is detailed in two ledgers, the first covering 1798-1805, and the second from 1806-1812 (TFP, WCL, Box 8. John Tailyour's will only recorded assets of $£ 33,563$ but, barring some kind of financial calamity in $1813 / 14$, this must be a massive underreporting, as Tailyour's own ledger records a net worth of $£ 96,889$ sterling on 31 December 1812 (Register of Inventories and Settlements 31 August 1815-26 May 1817, NAS, CC20/7/8). Tailyour likely transferred a large amount of his property immediately prior to his death, so as to avoid taxation.

${ }^{48}$ John Tailyour to Hercules Tailyour, Kingston, 7 June 1783, TFP, WCL, Letterbook 1781-1785 ("friendship" quote). For Tailyour's purchase of landed estates, see John Tailyour to Simon Taylor, PLC, XIV/135-142; Simon Taylor to John Tailyour, Kingston, 18 February 1797, TFP, WCL, Box 7. For John Tailyour's will, see Register of Inventories and Settlements 31 August 1815-26 May 1817, NAS, CC20/7/8. Peter Ballantine to John Tailyour, Kingston, 14 December 1793, TFP, WCL, Box 1; John Tailyour to Simon Taylor, Craigo, 26 April 1799, PLC, XIV/152. The average price of captives for 1793 has been taken from Voyages. David Duncombe to Lowbridge Bright, Kingston, 19 June 1790 in Ibid., p.546 ("at least” quote).
} 


\section{Guinea Factors in Jamaica}

John Tailyour's partners also grew rich by the Jamaican slave trade. Both Ballantine and Fairlie had, like Tailyour, begun their careers in the Virginia tobacco trade in the 1770s, before relocating to Kingston under the auspices of a Glasgow merchant house. Because of the American Revolutionary War, they began their co-partnership, as James Fairlie put it, "without a sixpence," and so drew loans from their family members, including Fairlie's East-India nabob brother. Ballantine and Fairlie slowly built their capital base through town factoring, enabling them to join Tailyour's Guinea factoring business in 1792. When Tailyour left the company in 1796, Ballantine and Fairlie decided to use their profits stemming from TB\&F_—"upwards of $£ 20,000$ [sterling]" for each of the partners - to remain in Jamaica and "sell 1500 or 2000 Negroes annually," turning over $£ 80,000$ per annum, in addition to $£ 12-14,000$ from their town factoring business. After quitting Jamaica in 1799, Ballantine and Fairlie returned to Scotland, and used their West India fortunes to purchase landed estates, where they died, like Tailyour, as rich men. ${ }^{49}$

Reflecting on his success in business, Tailyour boasted in 1799 that he built his fortune solely on credit, something that was enabled by Simon Taylor, who put his own considerable wealth behind his cousin. One could argue, then, that Tailyour, and by association Ballantine and Fairlie's, reliance on Taylor-one of the richest men in the British Empire-makes him unrepresentative of other Guinea factors, enabling him to obtain super-profits that were beyond the reach of other firms. While it is true that other firms did not have such an affluent relative underwriting their business, they still held their own advantages. Liverpool companies possessed ready-made British networks that they used to secure a supply of slave ships and other merchants,

\footnotetext{
${ }^{49}$ James Fairlie to Robert Findlay \& Company, Kingston, 22 December 1783, James Fairlie Letterbook, Glasgow City Archives, NRAS905/4 ("sixpence" quote); James Fairlie to William Fairlie, Kingston, 15 July 1796, Ibid. ("upwards" quote); James Fairlie to Mungo Fairlie, Kingston, 16 July 1796, Ibid. ("sell” quote). Peter Ballantine died of tetanus on 4 June 1810 aged fifty-eight, following a riding accident on his Castlehill estate (William Kelso to John Tailyour, Castlehill, TFP, WCL, Box 3). James Fairlie died on his Belfield estate on 19 May 1819, aged seventy-seven (The Gentleman's Magazine, 125, 1819, p.586).
} 
like the long-time Jamaica resident Alexandre Lindo, had a well-developed "country interest" that enabled them to attract affluent and reliable planter purchasers to their sales. These firms were sufficiently competitive to land more captives than Tailyour in ten out of the twelve years that he was active as a Guinea factor (Table 3). While unrepresentative of the multitude of small merchant houses that tried, and usually failed, to break into Guinea factoring, Tailyour's biography illustrates well how a handful of large Jamaican companies controlled the majority of the island's slave trade and profited enormously by it (Table 1). ${ }^{50}$

Tailyour's success certainly seems unexceptional when we consider the wealth of other leading Jamaican Guinea factors. Alexandre Lindo amassed a portfolio of plantations, town houses, ships, and furniture through his business, which in 1802-3 he used to loan the French army in Saint Domingue the staggering sum of $£ 500,000$ sterling. Outside of the period of Tailyour's career, Thomas Hibbert, who had been "the most eminent Guinea factor in Kingston" before the American War, died in 1780, and, according to his friend Nathanial Phillips, left $£ 215,000$ sterling to his three nephews, who themselves worked as slave traders in the 1780s. The Hibbert family's story was literally one of rag to riches via the slave trade: "The Family were all weavers," Simon Taylor wrote to John Tailyour's brother in 1800, "and [Thomas Hibbert] ... was sent to this country to collect some debts and got acquainted with a Guinea factor who took him into partnership and by the sale of negroes alone made his fortune." Edward Foord, Samuel Delpratt and Richard Clarke, Hibbert's major competitors, all died between 1777 and 1783 holdings assets collectively totaling $£ 266,466$ sterling. Their contemporary Scudamore Winde, who operated a large slave factoring firm from at least 1773 , possessed $£ 67,337$ sterling upon his death in 1776 ; his partner

\footnotetext{
${ }^{50}$ John Tailyour to Simon Taylor, Craigo, 26 April 1799, PLC, XIV/152. John Tailyour to John \& Alexander Anderson, Kingston, 19 October 1788, TFP, WCL, Letterbook 1788-9.
} 
Alexander Allardyce was said, in 1790, to have "made his fortune" through the business. By comparison, David Pope found that of 178 leading Liverpool slave trading merchants — by far Britain’s largest investors in slave ships—only nine had estates exceeding $£ 30,000 .^{51}$

Guinea factoring was one of the most lucrative branches of the slave trade, bringing exceptionally large profits that exceeded those to be earned in the direct shipping of captives, a result of the first being a commission business, and the second a speculative investment. Guinea factors received fixed commissions, offering a guaranteed return regardless of a voyage's outcome. By contrast, slave traders — who owned both the slaving vessels and the slaves they carried — sold slaves at potentially massive gains or losses depending on the vagaries of the voyage. David Richardson calculated, for example, that William Davenport - one of Liverpool's leading slave trading merchants in the 1770 s and 1780 s and investor in at least 163 slaving voyages - earned profits of $£ 10,518$ over the course of his thirty-eight year career, but experienced wild fluctuations in his profits. Tailyour earned an equivalent fortune in 1794 alone, when his company sold nineteen shiploads of captives, all at fixed commissions. If commission businesses like Guinea factoring were, as Tailyour described them in 1784, "attended with little risque or uncertainty," the direct slave trade was, as a former slave ship captain aptly labelled it in 1789 , a "lottery."52

\footnotetext{
${ }^{51}$ After the French withdrawal from Saint-Domingue in 1803, the French government refused to honor Lindo's bills, wiping out the majority of his fortune. Lindo lived out the remainder of his life in London and died in 1812, leaving approximately $£ 50,000$ sterling to his family (Ranston, Lindo Legacy, pp.50-63). Sheridan, "Commercial," p.255 ("eminent" quote). Diary of Nathanial Phillips, 1780, JMSP, 9409. Simon Taylor to Robert Taylor, Kingston, 19 July 1800, Letterbook of Simon Taylor 1799-1800, PLC, XIII ("The Family" quote). Foord, Delpratt, Clark and Winde's wealth is from Trevor Burnard's analysis of the wills of 10,223 Jamaican whites who died between 1674 and 1787. David Pope, "The Wealth and Social Aspirations of Liverpool's Slave Merchants of the Second Half of the Eighteenth Century," in Richardson, Schwarz, and Tibbles eds., Liverpool and Transatlantic Slavery, pp.208-215; David Duncombe to Lowbridge Bright, Kingston, 19 June 1790 in Ibid., pp.547 ("made" quote).

${ }^{52}$ David Richardson, "Profits," in Anstey and Hair eds., Liverpool, pp.60-90; John Tailyour to John \& Alexander Anderson, Kingston, 28 February 1784, TFP, WCL, Letterbook 1781-5 ("attended" quote); Testimony of John Newton, Lambert ed., Sessional Papers, 73 (1790), p.145 (“lottery” quote).
} 


\section{Guinea Factors in Jamaica}

Of course, no business was entirely free from risk, and Guinea factors did fail, usually as a result of bad debts contracted with planters. Planters lamented that Guinea factors extended generous terms of credit which, they argued, lured them to slave sales and into debts they could not hope to pay. Guinea factors charged interest on these debts that, during prosperous periods, seems to have adequately covered the risk of default. During economic downturns, however, Guinea factors could be dangerously exposed by defaulting planters. In late 1804, for example, David Dick, who by then headed the successor firm to Tailyour's, wrote bitterly that the factoring business had become much less profitable because of a crisis in the Atlantic economy, which had made it difficult for factors to recover debts. Alexandre Lindo, Thomas Hardy, and Alexander Shaw, all factors that, according to Dick, had "made their fortunes" in Tailyour's time, were by then suffering difficulties. Shaw, who had boasted of his massive slave smuggling profits to Cutting in 1790, had died, Dick wrote, with a broken heart and was “ $£ 50,000$ worse than nothing." Guinea factors in other time periods and colonies also failed. During the 1750s, the Harvies, a family of Scottish merchants, tried to break into the "beneficial" Jamaican Guinea factoring business, but soon failed after contracting lengthy and bad debts. Likewise, the Baillie family company, one of the premier slave factoring firms in the Windward Islands, and Alexander Houston \& Company, a guarantee for a slave factoring firm in Grenada, both collapsed in the late 1790s. It would appear, then, that Tailyour's success can be traced, in part, to his ability to manage risk during a particularly lucrative time for Guinea factors. ${ }^{53}$

Even so, the rapidity with which John Tailyour built his fortune via Guinea factoringfrom $£ 1,500$ to almost $£ 82,000$ sterling in just fifteen years-demonstrates that historians should

\footnotetext{
${ }^{53}$ For the interest on debts, see John Tailyour to John \& Alexander Anderson, Kingston, 17 July 1785, TFP, WCL, Letterbook 1781-5. For complaints about credit terms, see William Beckford, A Descriptive Account of the Island of Jamaica, (London, 1790), pp.337-8. David Dick to John Tailyour, Kingston, 29 August 1804, TFP, WCL, Box 2 ("made” quote). Smith, Slavery, Family, pp.195-207 ("beneficial” quote). Hamilton, Scotland, pp.101-106.
} 


\section{Guinea Factors in Jamaica}

return to the long ignored question of the slave trade's profitability. While Tailyour's case does not prompt a return to the Williams thesis - he having invested his capital in landed property and government bonds - it certainly shows that the slave trade could be extremely profitable for merchants who sold slaves in the Americas, rather than investing in slaving vessels. Few men could access these profits because Guinea factoring was an oligopoly whose participants needed family connections to enter the business, and networks of influential and affluent correspondents in order to succeed. Young men like John Tailyour could not arrive in Jamaica without established clients and commence selling expensive captive Africans to anonymous planters. They had instead to build, through town factoring, a "country interest" of creditworthy Jamaican planters, and a parallel network of elite British slaving merchants. By collecting commissions on the thousands of African slaves that they sold into slavery, Guinea factors like John Tailyour thus made their fortunes.

On 19 December 1789, John Tailyour informed his cousin Simon Taylor that the slave ship Hester had recently sailed into Kingston with 299 African captives consigned to his factoring house by the Bristol slaver James Jones. Three weeks later, opened the Hester's sale and picked out eight "prime" men and one woman for the Golden Grove plantation, a sugar estate under his cousin's management. Upon their arrival there, Simon Taylor named three of the "New Negroes" after his family, himself and his cousin: Taylor, Simon, and John. Perhaps with a cruel sense of irony, he had labelled the three slaves with names that encapsulated the important role that he, a planter, and his cousin, a Guinea factor, played in the forced migration of the Hester's captives from Africa. The Hester had sailed to Kingston because its owner James Jones had contracted, via Simon Taylor, with John Tailyour. Once arrived at Kingston, Simon, John and Taylor had been purchased 
for Golden Grove because of Tailyour's relationship with his cousin. Using commissions earned, in part, from the sale of the Hester's slaves, John Tailyour retire to a life of leisure in his native Scotland, while his namesakes John and Taylor toiled in Golden Grove's field gang, never to return to their own homes in Africa. If historians want to explain the movement of slaves like John, Simon and Taylor, they should thus study the business histories of slave traders like John Tailyour who, through their desire for profits, created migratory pathways along which millions of enslaved Africans were forcibly transported. ${ }^{54}$

The case of John Tailyour also demonstrates that historians should take a broader view of the trans-Atlantic slave trade that goes beyond the Middle Passage. By focusing on the Middle Passage, abolitionists have left us arresting mental and visual images of hundreds of captives squeezed into the fetid holds of Guineamen as they were dragged across the Atlantic. Indeed, the famous diagram of the Brooks, a vessel that John Tailyour would have seen riding at anchor in Kingston harbor, perhaps encapsulates more than any other image our conception of the slave trade. Yet, as we have seen, American slave sales were traumatic, and often lengthy, processes that determined, more than the Middle Passage, the ultimate fate of captive Africans in the Americas. Other important aspects of the slave trade have been equally neglected by historians. Once brought to plantations, enslaved Africans underwent a three year "seasoning" period that is shrouded in mystery, given the paucity of research on the subject. We also know little about slave sales were conducted in Africa, or, after their sale, the many months that captives spent imprisoned on an anchored ship awaiting departure from the African coast. Focusing solely on the Middle Passage

\footnotetext{
${ }^{54}$ For the Hester's sale, see John Tailyour to Simon Taylor, Kingston 19 December 1789, PLC, XIV/47, 48; John Tialyour to James Jones, Kingston, 26 December 1789, 24 January 1790, TFP, WCL, Letterbook 1788-9. The time between the arrival of the Hester and the opening of the sale was unusually long because of Christmas and New Year. For the Golden Grove slaves, see "Negroes Bought of Sundries for $1^{\text {st }}$ January 1791," PLC, VANNECKARC/3A/1790/47.
} 


\section{Guinea Factors in Jamaica}

ignores these crucial phases in the enslavement of Africans, all of which lasted longer the transAtlantic voyage. We must, therefore, expand our vision to encompass the "Long Middle Passage," the often years-long process by which millions of Africans were enslaved in the Atlantic World. 